\author{
Michał Przeperski \\ https://orcid.org/0000-0003-2712-5711 \\ Instytut Historii Nauki PAN / Biuro Badań Historycznych IPN
}

\title{
Anatomia kreacji. Przypadek Dzienników politycznych Mieczysława F. Rakowskiego
}

Zarys treści: Tekst stanowi analizę dziennika prowadzonego przez 40 lat przez Mieczysława Rakowskiego, stanowiącego uniwersalne, szeroko używane źródło do najnowszych dziejów Polski. Szczególny nacisk został położony na uwypuklenie zróżnicowanych zmian wprowadzonych przez autora w trakcie przygotowania go do druku w latach 1998-2005, dzięki czemu tekst zawiera gruntowną krytykę tego źródła i formułuje postulaty co do jego badawczego zastosowania na przyszłość.

Abstract: The text is an analysis of a journal kept for forty years by Mieczysław Rakowski, presenting a universal, widely used source for the recent history of Poland. Special effort is made to emphasise the various changes introduced by the diary's author during the preparation of the text for publication in 1998-2005; this made it possible to present a thorough critique of this source and put forward postulates as to its scholarly use in the future.

Słowa kluczowe: Mieczysław Rakowski, dzienniki polityczne, dziennik, diarystyka, biografistyka, źródłoznawstwo

Keywords: Mieczysław Rakowski, political diaries, diary, diary studies, biographical studies, source studies

„Należy przyjąć, że wydane «Dzienniki polityczne» mają podwójną naturę: są częściowo (w większości) autentycznymi zapiskami, które powstały równocześnie z opisywanymi wydarzeniami, a częściowo rodzajem wspomaganych źródłami wspomnień ubranych w formę dziennika. Myślę, że stan taki nie dyskwalifikuje tego opus magnum Rakowskiego, nakazuje jednak pewną ostrożność w korzysta-

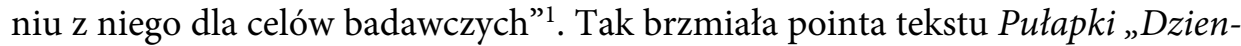
ników” Rakowskiego, opublikowanego w kwietniu 2013 r. w tygodniku „Polityka”. Jego autor, Andrzej Paczkowski, jako pierwszy zwrócił uwagę na rozbieżności

${ }^{1}$ A. Paczkowski, Pułapki „Dzienników” Rakowskiego, „Polityka” 2013, nr 15, s. 56-57. 
pomiędzy wersją dziennika Mieczysława F. Rakowskiego znajdującą się w Hoover Institution Archives w Stanford, a monumentalną, dziesięciotomową wersją opublikowaną nakładem wydawnictwa „Iskry” w latach 1998-2005. Jednocześnie sformułował wówczas postulat, by pogłębić badania nad spuścizną diarystyczną Rakowskiego. Niniejszy tekst podejmuje to wyzwanie.

Dzienniki Rakowskiego cieszą się sławą jednego z najważniejszych źródeł do szeroko rozumianych dziejów PRL. Ich wartości poświęcono w literaturze sporo miejsca, refleksje na ten temat snuli m.in. Tomasz Mielczarek ${ }^{2}$, Iwona Hofman ${ }^{3}$, Marceli Kosman ${ }^{4}$, Sławomir Stępień ${ }^{5}$, Andrzej Friszke ${ }^{6}$, Paweł Machcewicz ${ }^{7}$, Łukasz Dwilewicz i Jacek Luszniewicz ${ }^{8}$ czy Jerzy Eisler ${ }^{9}$. Dzienniki polityczne stały się też główną podstawą źródłową cząstkowych opracowań istotnych tematów, takich jak np. dzieje Kościoła katolickiego ${ }^{10}$ czy szeroko rozumiane wizje socjalizmu ${ }^{11}$, a także trudnej do oszacowania liczby rozmaitych prac dyplomowych ${ }^{12}$. Niezliczone odwołania do opus magnum Rakowskiego odnajdziemy w studiach dotyczących różnych gałęzi historiografii; tym bardziej warto zatem pogłębić refleksję nad tak powszechnie wykorzystywanym źródłem do dziejów PRL.

W trakcie prac nad biografią polityczną Mieczysława Rakowskiego miałem okazję poznać pierwotną wersję dziennika, a także wersje pośrednie, powstające w czasie prac wydawniczych nad publikacją Dzienników politycznych. Niniejszy tekst stanowi próbę podsumowania tych badań. Stawiam sobie za cel uchwycenie sposobów prowadzenia zapisków przez autora, jak i ich modyfikowania, rozważania

2 T. Mielczarek, Dzienniki polityczne 1958-1962, „Rocznik Historii Prasy Polskiej” 1999, nr 1, s. $170-173$.

${ }^{3}$ I. Hofman, Dylematy moralne Mieczystawa F. Rakowskiego w „Dziennikach politycznych”, w: Polityka a moralność, red. M. Szyszkowska, T. Kozłowski, Warszawa 2001, s. 145-152.

${ }^{4}$ M. Kosman, Dokumentalista cieni władzy. Nad dziennikami politycznymi byłego premiera Polski, w: Z rozważań nad kultura polityczną w Polsce. Część druga, Poznań 2001, s. 37-56.

${ }^{5}$ S. Stępień, Dziennik jako źródło do badania historii PRL (na przykładzie „Dzienników politycznych” Mieczysława F. Rakowskiego), w: „Polska 1944/45-1989, Studia i Materiały” 6, 2003, s. 203-228.

${ }^{6}$ A. Friszke, Diariusz Rakowskiego, „Polityka” 2005, nr 37, s. 15-19.

7 P. Machcewicz, „Stuchać potulnie albo odejść”. O „Dziennikach politycznych” Mieczysława Rakowskiego, w: idem, Spory o historię 2000-2011, Kraków 2012, s. 78-84.

${ }^{8}$ Ł. Dwilewicz, J. Luszniewicz, „Dzienniki polityczne” jako klucz do Rakowskiego, w: Ekonomia, społeczeństwo, polityka. Studia ofiarowane prof. dr hab. Januszowi Kalińskiemu w 70. rocznicę urodzin, Warszawa 2012, s. 249-276.

9 J. Eisler, Siedmiu wspanialych. Poczet pierwszych sekretarzy KC PZPR, Warszawa 2014, s. 457-460.

${ }^{10}$ R. Łatka, Obraz Kościoła katolickiego w latach osiemdziesiątych w „Dziennikach politycznych” Mieczysława Rakowskiego, „Zeszyty Historyczne WiN-u” 2013, nr 38, s. 121-158.

${ }^{11}$ S. Czapnik, Rozważny i romantyczny? Wizje socjalizmu w dziennikach Ernesto Che Guevary i Mieczystawa F. Rakowskiego, „Nowa Krytyka” 2017, nr 39, s. 99-122.

12 Warta wspomnienia jest zwłaszcza, oparta na materiałach archiwalnych ze zbiorów Hoover Institution Archives, praca magisterska Bartosza Różanka pt. Grudzień 1981 r. w „Dziennikach politycznych" Mieczysława F. Rakowskiego - studium źródłoznawcze, napisana pod kierunkiem dr hab. Ewy Syski w Instytucie Historii Uniwersytetu im. Adama Mickiewicza w Poznaniu w 2018 r. 
te ilustrując przykładami. Formułuję hipotezy na temat możliwych motywacji przyświecających autorowi dziennika, by w końcu podjąć próbę oceny źródłowej wartości Dzienników politycznych i sformułować postulaty badawcze na przyszłość.

\section{Decyzja o publikacji}

„Jakaż to ciekawa lektura. Myślę, że powinienem już przystąpić do opracowania”13 - zanotował Mieczysław Rakowski w początku grudnia 1992 r., przeczytawszy szerszy fragment własnych dzienników, prowadzonych sukcesywnie od $1958 \mathrm{r}$. Dlaczego w ogóle zaczął je spisywać? Na to pytanie nie ma jednej przekonującej odpowiedzi. Z pewnością ważne znaczenie miał jego egotyzm, w nieoczywisty sposób łączący się z pasją historyka. Nie bez kozery już w maju 1961 r. Rakowski określał pisanie dziennika jako „pracę «dla historii»"14. Znaczenie miało i to, o czym w kontekście własnego dziennika pisała Hanna Świda-Ziemba: prowadzenie regularnego dialogu z samym sobą „stanowiło formę osobistej terapii, czyniło życie mniej uciążliwym"15. Tak rozumiane intymne zapiski stanowiły platformę, na której autor mógł wreszcie być w pełni szczery, co miało wyjątkowe znaczenie w kontekście realiów PRL naznaczonych cenzurą oraz rozmaitymi formami autocenzury.

Już w 1991 r. w książce Jak to się stało Rakowski opublikował fragmenty dziennika z 1981 r. ${ }^{16}$ Rok później, przy okazji publikacji wywiadu rzeki Zanim stane przed trybunałem, przygotowanego w ekspresowym tempie we współpracy z Dariuszem Szymczychą, opublikowane zostały fragmenty dziennika z roku $1990^{17}$. Ponieważ publikacja tej książki zbiegła się z poważnymi kłopotami zdrowotnymi autora, jej promocja była bardzo utrudniona. Stało się to jednym z powodów, dla których książka ta nie powtórzyła sukcesu wydawniczego Jak to się stało. Po powrocie do zdrowia, Rakowski przygotował publikację Lata, listy, ludzie. Adresat M.F. Rakowski ${ }^{18}$, złożoną z listów kierowanych do niego na przestrzeni lat, i domykającą serię zapoczątkowaną jeszcze w pierwszej połowie lat $80 .{ }^{19}$ W tym samym czasie krystalizował się pomysł, by upublicznić choćby część swojej

\footnotetext{
${ }^{13}$ Hoover Institution Archives (dalej: HIA), Mieczysław F. Rakowski papers (dalej: MFR papers), Box 7, Dziennik 1992, k. 121 (3 XII 1992).

${ }^{14}$ HIA, MFR papers, Box 1, Dziennik - t. 4, k. 9 (27 V 1961).

${ }^{15}$ H. Świda-Ziemba, Człowiek wewnętrznie zniewolony. Problemy psychosocjologiczne minionej formacji, Warszawa 1998, s. 8.

${ }^{16}$ M.F. Rakowski, Jak to się stało, Warszawa 1991, s. 23-30.

${ }^{17}$ Zanim stane przed trybunałem. Z Mieczysławem Rakowskim rozmawia Dariusz Szymczycha, [Warszawa 1992], s. 141-156.

${ }^{18}$ Lata, listy, ludzie. Adresat M.F. Rakowski, Warszawa 1993.

${ }^{19}$ Od sierpnia do grudnia 1980. Listy do Mieczystawa F. Rakowskiego, Warszawa 1981; Listy do M.F. Rakowskiego. Listopad-grudzień 1982, Warszawa 1983; Stocznia Gdańska Sierpień '83. Listy do wicepremiera M.F. Rakowskiego, Warszawa 1983.
} 
diarystycznej spuścizny. W kwietniu 1994 r. Roman Górski, szef wydawnictwa BGW, proponował Rakowskiemu publikację „wypisów z dzienników”20. Sam Rakowski szacował, że praca ta - zakładając, że obejmie zapiski z lat 1980-1995 - zajmie przynajmniej trzy lata. Na przeszkodzie realizacji tych planów stanęła jednak fatalna sytuacja finansowa BGW. Koniunktura na wspomnienia działaczy komunistycznych, zapoczątkowana publikacją Przerwanej dekady - bestsellerowego wywiadu rzeki Janusza Rolickiego z Edwardem Gierkiem - wyraźnie wyhamowała, by skończyć się w połowie lat dziewięćdziesiątych.

Pomysł publikacji dzienników nie dawał jednak Rakowskiemu spokoju. Ówczesny redaktor naczelny miesięcznika „Dziś. Przegląd Społeczny” był już wówczas poza głównym nurtem wydarzeń politycznych w kraju, a zapewne pragnął podtrzymać zainteresowanie swoją osobą. Jeszcze wiosną 1992 r. wyrażał nadzieję, że dopomoże mu w tym książka o Gorbaczowie: „liczę, że znajdzie oddźwięk za granicą, a może i również pomóc tu w kraju, w przywróceniu mojemu nazwisku miejsca (godziwego) w opinii publicznej"21. Biografia ostatniego przywódcy ZSRR nie przyniosła jednak spodziewanego efektu ${ }^{22}$.

Bez wątpienia publikacji dzienników towarzyszyły również inne motywacje. W ocenie Rakowskiego stanowiła ona szansę na wykreowanie własnej wizji historii, alternatywnej wobec tej tworzonej przez autorów jednoznacznie krytycznie oceniających dorobek PRL, których prace wyszły wreszcie z podziemia i nadawały ton refleksji o minionej epoce. Rakowski, podobnie jak kilku innych przedstawicieli dawnego systemu, czuł się w obowiązku bronić dobrej pamięci o Polsce Ludowej. Przy okazji, a może przede wszystkim, bronił także swojej biografii. O tym, jak ważna była to dla niego sprawa, świadczą chociażby uwagi poczynione na marginesie książki Jacka Kuronia i Jacka Żakowskiego PRL dla początkujących. „Opowieść Jacka [...] jest znacznie bardziej uczciwa niż wiele innych książek poświęconych PRL a napisanych przez historyków typu [Normana] Davisa, [Andrzeja] Paczkowskiego czy [Wojciecha] Roszkowskiego"23 - zanotował Rakowski w październiku 1995 r.

W końcu, publikacja Dzienników politycznych stała się możliwa dzięki Wydawnictwu „Iskry”. Rakowski wspominał o tym, że dał się przekonać perswazjom prezesa Wiesława Uchańskiego ${ }^{24}$. Ten drugi wspominał natomiast, że inicjatywa wyszła od autora, co wydaje się znacznie bardziej prawdopodobne. Początkowo zresztą mowa była raczej o 3-4 tomach, szczególnie że sam Rakowski miał problemy z oszacowaniem objętości własnych zapisków ${ }^{25}$. Ostatecznie

\footnotetext{
${ }^{20}$ HIA, MFR papers, Box 7, Dziennik 1994, k. 86 (27 IV 1994).

${ }^{21}$ HIA, MFR papers, Box 7, Dziennik 1992, k. 25 (13 III 1992).

22 M.F. Rakowski, Gorbaczow. Pierwszy i ostatni, Warszawa 1992.

${ }^{23}$ HIA, MFR papers, Box 7, Dziennik 1995, k. 131 (12 X 1995).

${ }^{24}$ K. Masłoń, Chybiona prognoza, „Rzeczpospolita”, 6-7 VIII 2005.

${ }^{25}$ Relacja Wiesława Uchańskiego, 29 VI 2016, w zbiorach autora.
} 
to właśnie nakładem „Iskier” w latach 1998-2005 ukazało się monumentalne, dziesięciotomowe wydanie tej publikacji. W słowie od autora, otwierającym pierwszy tom, Rakowski pisał o swoich motywacjach w sposób niepozostawiający złudzeń co do celu przyświecającego temu projektowi: „Dzienniki polityczne ukazują się w czasie, gdy dzieje Polski Ludowej są nie tylko przedmiotem zainteresowań mniej lub bardziej uczciwych historyków, lecz także polityków orientacji prawicowej, którzy w dążeniu do wyeliminowania lewicy z życia politycznego kraju, względnie osłabienia jej wpływów, głoszą pogląd o przestępczym charakterze PRL i PZPR. Muszę więc brać pod uwagę, że mój zapis zostanie wykorzystany $\mathrm{w}$ walce $\mathrm{z}$ lewicą do której należę"26.

Niewątpliwie zatem autor dziennika miał świadomość, że jego świadectwo z epoki stanie się głosem współkształtującym dyskusję o najnowszych dziejach Polski. Rakowski był ich ważnym uczestnikiem i miał swoje wyraziste opinie nierzadko bardzo konsekwentnie podtrzymywane przez lata. Publikacja dziennika dawała mu szansę wyeksponowania własnej roli.

We wstępie do pierwszego tomu Rakowski podkreślał, że niczego nie upiększał i oparł się pokusie retuszowania własnego wizerunku ${ }^{27}$. Podobne deklaracje powtarzał później jeszcze wielokrotnie, broniąc wiarygodności swojego dzieła ${ }^{28}$. Czynił to zresztą na tyle skutecznie, że w naukowej krytyce edycji dzienników na dobrą sprawę nie formułowano poważniejszych zastrzeżeń wobec ich treści. Charakterystyczna była opinia sformułowana przez Pawła Wieczorkiewicza w jego pełnym werwy - i nieścisłości - tekście z 2009 r., gdzie stwierdzał, że poprawek należy u Rakowskiego poszukiwać tam „gdzie ponosiło go pióro publicysty i używał określeń ogólnie uznawanych za zelżywe i w drugim wypadku - ostrych ocen postawy i poglądów gen. Jaruzelskiego, które formułował na swój użytek"29.

O tym, że zmiany te szły dalej, można było przekonać się, gdy obszerne osobiste archiwum Rakowskiego zostało udostępnione badaczom przez Hoover Institution Archives w Stanford, gdzie ten zdecydował się przekazać swoją spuściznę $e^{30}$. Można sądzić, że o takiej decyzji przesądził brak zaufania do polskich instytucji archiwalnych oraz do polskich historyków. Podejrzewam iż Rakowski był zdania, że z perspektywy USA łatwiej będzie o wyważone spojrzenie na jego życiorys. Tak czy inaczej, porównanie wersji opublikowanej dziennika z wersją przekazaną przez Rakowskiego do archiwum pokazuje, że wprowadził on w nim szereg poprawek, które zmieniają sens niejednego z pierwotnych zapisów.

\footnotetext{
${ }^{26}$ M.F. Rakowski, Dzienniki polityczne, t. 1: 1958-1962, Warszawa 1998, s. 6.

${ }^{27}$ Ibidem.

${ }^{28}$ A. Paczkowski, op. cit., s. 56-57; J. Eisler, op. cit., s. 457-460.

${ }^{29}$ P. Wieczorkiewicz, Jak Rastignac Polskiej Zjednoczonej Partii Robotniczej został Balzakiem Polskiej Republiki Ludowej, „Arcana” 2009, nr 86-87, s. 234.

${ }^{30}$ Relacja Macieja Siekierskiego, 20 VII 2015, w zbiorach autora.
} 


\section{Proces twórczy}

Swoje notatki dzienne Mieczysław Rakowski prowadził z pewnością przez przynajmniej czterdzieści lat, od wiosny 1958 r., aż po rok 1998 (ostatnie znane mi zapiski pochodzą z początku 1998 r.) $)^{31}$. Sądząc jednak po zawartości czterech tomów Polskiego przekładańca ${ }^{32}$, opierającego się częściowo na publikowanych w „Dziś. Przeglądzie Społecznym” Okruchach dziennika, mógł je prowadzić dłużej, być może do końca życia. Publikacji doczekała się jednak tylko ta część dziennika, która dotyczy okresu jego aktywnej działalności politycznej. Notatki prowadzone do początków lutego 1990 r. to świadectwo człowieka pnącego się po szczeblach kariery i stopniowo mającego coraz większy wpływ na bieg wydarzeń. Tymczasem dziennik emeryta - choć niepozbawiony pewnych walorów - po względem wartości źródłowej nie może się równać z zapiskami aktywnego polityka.

Dzienniki prowadzone przez Mieczysława Rakowskiego w latach 1958-1996 stanowią zawartość 25 spośród 95 pudeł archiwalnych w jego kolekcji przechowywanej w Hoover Institution Archives. $Z$ tego pierwsze siedem pudeł obejmuje "oryginały”, pudła 8-23 zawierają "poprawki edytorskie” (editorial revisions), natomiast w pudłach 24-25 znajduje się dziesięć tomów opublikowanych Dzienników politycznych ${ }^{33}$. W skład tej części zbiorów, którą umownie określa się mianem "oryginału”, wchodzą maszynopisy dziennika za lata 1958-1996. 50 pierwszych zeszytów dzienników, obejmujących okres od 1 stycznia 1958 do 24 września 1980 roku, to maszynopisy na kartkach w kratkę -formatu A5 lub B5. Wszystko wskazuje, że także i po wrześniu 1980 r. Rakowski przynajmniej przez pewien czas prowadził notatki w podobny sposób. Potwierdza to przechowywany w HIA fragment $\mathrm{z}$ grudnia $1981 \mathrm{r}$., sporządzony na luźnych kartkach w kratkę formatu $\mathrm{A} 5^{34}$ oraz znana mi kopia dziennika z pierwszych miesięcy roku $1981^{35}$. Jednak przechowywane w HIA maszynopisy obejmujące okres od września 1980 r. do końca 1996 r., oprócz wspomnianego fragmentu z grudnia 1981 r., sporządzone są wyłącznie na gładkich kartach A4 ${ }^{36}$.

Wersja dzienników, którą określamy mianem „oryginału”, nie jest w rzeczywistości pierwszą wersją zapisków. Sądząc po jakości maszynopisu, choć niewolnego

${ }^{31}$ HIA, MFR papers, Box 92, Notatki ze stycznia 1998.

${ }^{32}$ M.F. Rakowski, Polski przekładaniec, t. 1-4, Toruń 2002-2007.

${ }^{33}$ Register of the Mieczystaw F. Rakowski papers, http://www.oac.cdlib.org/findaid/ark:/13030/ c89024cn/dsc/\#ref13 (dostęp: 15 I 2020).

${ }^{34}$ HIA, MFR papers, Dziennik 1981, k. 1-36 (5-26 XII 1981).

${ }^{35}$ M.F. Rakowski, Dziennik 1981 - kopia (5 I-1 III 1981), w zbiorach autora.

${ }^{36}$ Porównanie kopii dziennika z początków 1981 r. sporządzonej na kartkach w kratkę w formacie A5 (M.F. Rakowski, Dziennik 1981 - kopia (5 I-1 III 1981), w zbiorach autora) z treścią „oryginalnej” wersji dziennika z początku 1981 r. na gładkich kartkach formatu A4 przechowywanej w Hoover Institution Archives (HIA, MFR papers, Box 4, Dziennik 1981) pokazuje, że ich treść jest identyczna. 
od błędów, to jednak co do zasady równego i uporządkowanego, notatki nie były prowadzone od razu na maszynie, „na czysto”. Podstawą były codzienne notatki prowadzone odręcznie przez Rakowskiego. Udało mi się dotrzeć do kopii - jedynej mi znanej - odręcznych notatek dziennych prowadzonych przez autora, pochodząca z początku roku 1987. Stanowi ona cenne źródło, rzucające światło na to jak wyglądały notatki, które dały podstawę przepisanej maszynowo wersji dziennika. Zacytuję ją in extenso:

\section{3 styczeń, sobota}

W 1986 odpowiedziałem (osobiście) na 186 listów. W 1985 r. odpisałem na 141 listów, ale nie jestem pewien czy do końca roku prowadziłem statystykę. W tym roku będę bardzo szczegółowo notował wszystkie odpowiedzi.

$\underline{6 \text { styczeń, wtorek }}$

W kilkunastu chińskich miastach doszło do demonstracji studenckich. Studenci domagają się więcej demokracji. Opinie n.t. tego kto za nimi stoi są różne. Najczęściej mówi się, że stoi za nimi grupa reformatorów, która napotyka na silny opór konserwy (oczywiście chodzi o partię). Opinia ta głosi, że demonstracje studenckie są swego rodzaju „grupą nacisku”.

\section{$\underline{8 \text { styczeń, czwartek }}$}

Przed południem przyjąłem dziennikarza z „Republiki” (włoski dziennik) p. Violę. Mały, szczupły Włoch. Był u mnie już nie poraz pierwszy. Jutro ma wywiad z Generałem, który 12.1 udaje się do Włoch z oficjalną wizytą. Viola był b. zadowolony z moich objaśnień dotyczących sytuacji w PRL. Ciekawe czy wiernie przekaże to co mu powiedziałem.

Po południu u ambasadora kubańskiego. Dwugodzinna dyskusja n.t. polityki, którą ostatnio zainicjował Fidel Castro. Wystąpił ostro przeciwko korupcji kadry (rozmiary korupcji b. wielkie) i zaczął chwalić przewagę czynnika ${ }^{37}$

Zapis został sporządzony ręcznie na luźnej kartce z notatnika; pierwsza część (dotycząca 3 i 6 stycznia) innym długopisem lub piórem niż druga. Wydaje się on dawać pewne pojęcie co do tego jak wyglądały codzienne notatki przygotowywane przez Rakowskiego, przynajmniej w okresie, gdy sprawował on funkcję wicemarszałka Sejmu PRL (1985-1988). Ciekawostką jest zresztą fakt, że musiała się ona autorowi zagubić, w efekcie czego zapisy z niej nie trafiły ani do „oryginalnej" wersji dziennika ${ }^{38}$, ani - co za tym idzie - do wersji opublikowanej przez „Iskry”. Jej miejsce zajęły uzupełnienia, dokonane już na etapie edycji około roku 2004, oparte na dokumentach, publikacjach z epoki oraz refleksjach bardziej ogólnej natury ${ }^{39}$.

\footnotetext{
${ }^{37}$ Notatka Mieczysława Rakowskiego [styczeń 1987], w zbiorach autora.

38 Zapisy za rok 1987 zaczynają się dopiero 11 stycznia 1987 r. (HIA, MFR papers, Box 6, Dziennik 1987, k. 1).

${ }^{39}$ HIA, MFR papers, Box 21, Dziennik 1987, k. 1-7 (2-10 I 1987); M.F. Rakowski, Dzienniki polityczne, t. 10: 1987-1990, Warszawa 2005, s. 11-20 (2-10 I 1987).
} 
Niełatwo o jednoznaczne i przekonujące wnioski jeżeli chodzi o techniczną stronę prowadzenia dziennika - mówimy przecież o długotrwałym procesie, trwającym z górą cztery dekady. Uogólniając można jednak stwierdzić, że część notatek Rakowski mógł zapisywać na maszynie, lecz zapewne większość ręcznie, piórem, później długopisem, najczęściej na luźnych kartkach. Wydaje się pewne, że pierwotne notatki odręczne, po przepisaniu ich na maszynie, zostały przez samego autora zniszczone lub wyrzucone. Syn Rakowskiego, Włodzimierz, w udzielonej mi relacji przypominał sobie, że przypadkiem odnalazł taką dzienną notatkę pośród papierów przeznaczonych na makulaturę ${ }^{40}$. Notatki były przez Rakowskiego przepisywane na maszynie, po pewnym czasie od sporządzenia ich pierwotnej wersji notatek, trudno precyzyjnie wskazać jak długim. Dziennik był przepisywany w kilku kopiach, co pozwalało na ukrywanie ich (np. w mieszkaniach przyjació $^{41}$ ) w chwilach wyjątkowego politycznego napięcia. Wydaje się, że np. notatki z pierwszych lat były opracowywane stosunkowo szybko, po roku lub dwóch od opisywanych wydarzeń. Świadczyć o tym mogą np. adnotacje Rakowskiego na niektórych zeszytach dziennika, gdzie autor zapisywał swój aktualny adres ${ }^{42}$.

Najprawdopodobniej już na etapie przepisywania na maszynie swoich dziennych notatek, Rakowski porządkował je, odsiewał pewne informacje, inne zaś dodawał. Wskazuje na to np. przepisywanie fragmentów dokumentów jakimi dysponował, np. listu Biura Prasy KC do redakcji „Polityki” z listopada 1960 r., który miał bardzo istotne znaczenie w kontekście kryzysu w jakim znalazła się wówczas redakcja tygodnika ${ }^{43}$. Innym charakterystycznym przykładem jest zapis ze spotkania w KC z czerwca 1962 r., na którym Kazimierz Świtała wespół z Kazimierzem Witaszewskim strofowali dziennikarzy. Rakowski wykorzystał informacje zawarte w notatce, którą najpewniej przygotował w czasie spotkania ${ }^{44}$, przy tworzeniu „oryginalnej” wersji zapisków ${ }^{45}$, która następnie, w takiej samej formie, znalazła się w opublikowanej wersji Dzienników politycznych ${ }^{46}$. Chociaż spotkanie odbyło się 20 czerwca $^{47}$, to każdorazowo jest ono opisywane we wpisie pod datą 19 czerwca.

\footnotetext{
${ }^{40}$ Relacja Włodzimierza Rakowskiego, 18 II 2017, w zbiorach autora.

${ }^{41}$ Relacja Bronisława Bednarza, 31 III 2015, w zbiorach autora.

42 Przykładowo: adres Kniewskiego 9 m. 10 na trzecim zeszycie, obejmujący okres od października 1960 r. do marca 1961 r. (HIA, MFR papers, Box 1, Dziennik - t. 3 (1 X 1960 - 13 III 1961)). Pod tym adresem Rakowski mieszkał do połowy lat 60 .

${ }^{43}$ HIA, MFR papers, Box 1, Dziennik - t. 3, k. 10-11 (6 XI 1960); Gomułka i inni. Dokumenty $z$ archiwum KC (1948-1982), wstęp, wprowadzenia i przypisy J. Andrzejewski [A. Paczkowski], Londyn 1987, s. 182-184. Por. M. Przeperski, Janczar Gomulki. Pozycja polityczna Mieczysława Rakowskiego w latach 1956-1970, „Polska 1944/45-1989. Studia i materiały” 11, 2013, s. 209-233.

${ }^{44}$ HIA, MFR papers, Box 80, Notatka z zebrania w KC, 20 VI 1962.

${ }^{45}$ HIA, MFR papers, Box 1, Dziennik - t. 6, k. 39-41 (19 VI 1962).

${ }^{46}$ M. F. Rakowski, Dzienniki polityczne..., t. 1, s. 399-400 (19 VI 1962).

${ }^{47}$ Archiwum Akt Nowych, Komitet Centralny PZPR, 237/XIX-151, Stenogram narady zwołanej przez Biuro Prasy i Wydział Administracyjny KC, 20 VI 1962, k. 77-177.
} 
Z czasem okres, po jakim Rakowski siadał do uporząadkowania, przepisania i zapewne - opracowania swoich notatek wydłużał się. Wydaje się, że „oryginalna” wersja dzienników za lata 1981-1989 została przez niego w lwiej części opracowana już na politycznej emeryturze. Nie są to maszynopisy w pełni czyste, zdarzają się w nich pomyłki pisarskie, nie odnajdziemy w nich natomiast oczywistych błędów merytorycznych (np. dotyczących nazwisk). Tymczasem tego rodzaju błędy są charakterystyczne dla „oryginałów” dzienników z lat 1991-1996 ${ }^{48}$. Wskazuje to, że te ostatnie były prawdopodobnie przepisywane z notatek przez maszynistki z redakcji miesięcznika „Dziś”, które choć cieszyły się zaufaniem naczelnego, to jednak nie miały pełnej orientacji co do jego rozległych znajomości.

Prowadzeniem notatek Rakowski nie zajmował się codziennie, jednak, co do zasady, często i regularnie, w zdyscyplinowany sposób. Kilkutygodniowe przerwy zdarzały się w początkach prowadzenia dziennika (np. jesienią 1958 r.) ${ }^{49}$, albo też w sytuacjach wyjątkowych z punktu widzenia osobistego lub z powodu nadmiernego obciążenia pracą (np. latem $1972 \mathrm{r}^{50} \mathrm{czy}$ latem ${ }^{51}$ oraz jesienią ${ }^{52}$ 1979 r.). Wiele $\mathrm{z}$ tych przerw zostało zamaskowanych $\mathrm{w}$ opublikowanej wersji dziennika - nie wszystkie umiejętnie. Na przykład „oryginalna” wersja dziennika z 1965 r. ma przerwę w ciągłości notatek pomiędzy 18 września a 10 listopada. Tymczasem w wersji „Iskier” - choć w latach dziewięćdziesiątych autor dodał jeszcze zapisy z 3,17 oraz 30 października ${ }^{53}$ - pod datą 10 listopada przeczytamy: „Już prawie półtora miesiąca nie zaglądałem do notatnika” ${ }^{54}$, co stanowi odzwierciedlenie zapisu „oryginalnego" ${ }^{5}$. Nielogiczność tego zapisu umknęła uwadze autora i redakcji.

Dla historyka badającego dzieje polityczne najistotniejsze będą luki dotyczące tych momentów, gdy znaczenie polityczne Rakowskiego było największe. Najistotniejszą wyrwą tego rodzaju jest brak zapisów w „oryginalnej” wersji dziennika w pierwszych miesiącach istnienia „Solidarności”, pomiędzy 24 września $1980 \mathrm{r}$.

\footnotetext{
${ }^{48}$ HIA, MFR papers, Box 7, Dzienniki 1991-1996.

49 „Prawie dwa miesiące nie zaglądałem do mojego notesu. Trudno będzie mi nawet przypomnieć sobie wszystkie zdarzenia z tego okresu", HIA, MFR papers, Box 1, Dziennik - t. 1, k. 36 (1 I 1959). Tego fragmentu nie znajdziemy w opublikowanej wersji. Zapisy z jesieni 1958 r. zostały bowiem uzupełnione w oparciu o inne źródła (M.F. Rakowski, Dzienniki polityczne..., t. 1, s. 44-74).

${ }^{50}$ HIA, MFR papers, Box 3, Dziennik - t. 34, k. 75 (2 VIII 1972); M. F. Rakowski, Dzienniki polityczne, t. 5: 1972-1975, Warszawa 2002, s. 55.

51 „Z lenistwa, a także ze zmęczenia, przez dwa miesiące nie zaglądałem do notatnika”, HIA MFR papers, Box 3, Dziennik - t. 47, k. 6 (20 VIII 1979); por. M.F. Rakowski, Dzienniki polityczne, t. 7: 1979-1981, Warszawa 2004, s. 87 (20 VIII 1979).

52 „Kilka dni temu powróciłem z miesięcznej podróży do Wenezueli”, HIA MFR papers, Box 3, Dziennik - t. 47, k. 7 (10 X 1979); por. Dzienniki polityczne..., t. 7, s. 102 (10 X 1979).

${ }_{53}$ M.F. Rakowski, Dzienniki polityczne, t. 2: 1963-1966, Warszawa 1999, s. 303-307.

${ }^{54}$ Ibidem, s. 307.

${ }^{55}$ HIA, MFR papers, Box 1, Dziennik - t. 14, k. 17 (10 XI 1965).
} 
a 5 stycznia $1981 \mathrm{r}^{56}$ Trzeba przyznać że lektura tego fragmentu w opublikowanej wersji Dzienników politycznych ${ }^{57}$ może zadziwiać. Uważnego czytelnika może zaskoczyć to, że dominuje w niej nie faktografia, choć tak wiele się wówczas w Polsce działo, a raczej opinie i refleksje ${ }^{58}$. Rakowski uzupełnił ten fragment dzienników w oparciu o dokumenty z prywatnego archiwum, co niezbicie potwierdza jedna $\mathrm{z}$ kolejnych wersji dopisków do dziennika przechowywana w Stanford ${ }^{59}$. W następnych miesiącach tak poważne przerwy już się nie zdarzały. Wnosząc po zachowanych dokumentach, Rakowski znajdował czas na sporządzanie notatek. Znajdziemy zapiski prowadzone od 5 stycznia do 1 marca 1981 r.; dłuższa przerwa obejmuje natomiast okres 1-21 marca. Jednocześnie jednak, niejeden $\mathrm{z}$ „oryginalnych” zapisków z wiosny $1981 \mathrm{r}$. ma jedynie szkicowy charakter, jak np. notatka z 10 kwietnia: „Sejm; wiele słów uznania dla mnie”, albo z 27 maja: „Dziś przyjeżdża Kulikow; w NRD i CSRS "czyszczą lufy»" ${ }^{61}$ - w obu przypadkach w wersji "Iskier” notatki z tych dni zostały poważnie rozbudowane, najpewniej dopiero na etapie przygotowań do publikacji ${ }^{62}$. Do końca 1981 r. dzienniki były prowadzone nieregularnie, wiele $\mathrm{z}$ nich stanowiło zapiski z posiedzeń różnych gremiów. Bardziej systematyczne notatki obejmują znów okres od 5 do 26 grudnia $1981 \mathrm{r}$.

12 lutego 1982 r., Rakowski odnotował w dziennikach, że „od tej pory wszystkie moje przeżycia, wszystkie moje uwagi będę utrwalał na taśmie magnetofonowej. Zaoszczędzę w ten sposób sporo czasu"63. Tym zapewne należy tłumaczyć brak pisemnych notatek za okres 12 lutego - 13 września 1982 r., za materiał podstawowy możemy uznać taśmy $\mathrm{z}$ nagraniami. Kolejnym ważnym momentem historycznym, w którym autor ewidentnie nie miał czasu na prowadzenie codziennych notatek jest jesień 1988 r., gdy formował swój gabinet (23 września 20 października 1988 r. $)^{64}$. Fragment opublikowany w edycji wydawnictwa „Iskry” ponownie został w całości napisany ok. roku 2004, w oparciu o różnego rodzaju dokumenty, m.in. listy i obszernie cytowane wycinki prasowe $\mathrm{z}$ tego okresu ${ }^{65}$.

\footnotetext{
${ }^{56}$ W „oryginalnej” wersji dzienników nie odnajdziemy zapisków za okres od 25 września 1980 r. od 5 stycznia $1981 \mathrm{r}$. Zostały one dopisane w trakcie przygotowań do edycji 7 tomu dzienników (Uzupełnienia: HIA, MFR papers, Box 15, Dziennik 1980, k. 90-131 oraz szereg stron nienumerowanych).

${ }^{57}$ M.F. Rakowski, Dzienniki polityczne..., t. 7, s. 257-307.

${ }^{58}$ Zob. P. Wieczorkiewicz, op. cit., s. 235.

${ }^{59}$ HIA, MFR papers, Box 15, Dziennik 1980, k. 90-131 oraz szereg stron nienumerowanych.

${ }^{60}$ HIA, MFR papers, Box 4, Dziennik 1981, k. 4 (10 IV 1981).

${ }^{61}$ HIA, MFR papers, Box 4, Dziennik 1981, k. 13 (27 V 1981).

${ }^{62}$ Dzienniki polityczne..., t. 7, s. 394-397 (10 IV 1981); Dzienniki polityczne..., t. 7, s. 423-424 (27 V 1981).

${ }^{63}$ HIA, MFR papers, Box 4, Dziennik 1982 (12 II 1982).

${ }^{64}$ HIA, MFR papers, Box 6, Dziennik 1988, k. 147-148 (23 IX 1988; 20 X 1988)

${ }^{65}$ HIA, MFR papers, Box 22, Dziennik 1988, k. 153-185 (24 IX-20 X 1988); M.F. Rakowski, Dzienniki polityczne..., t. 10, s. 236-264 (23 IX - 20 X 1988).
} 


\section{Uzupełnienia i skreślenia}

Jednym z najczęściej powracających pytań dotyczących Dzienników politycznych Rakowskiego jest na ile autor pozwolił sobie na dopiski, a na ile na skreślenia ${ }^{66}$. Nie ma wątpliwości, że jego dzienniki były ekstensywnie uzupełniane, czego dowodem jest fakt, że kolejne redagowane wersje dzienników znajdziemy w 15 spośród 95 pudeł jego spuścizny przechowywanej w Hoover Institution Archives.

Pierwszą z możliwych do wyróżnienia charakterystycznych kategorii uzupełnień są te o bardzo ogólnej treści, wspominające o rzeczach powszechnie znanych i zawierające opinie neutralne. Oto przykład notatki z 5 stycznia 1961 r., w całości stworzonej post factum:

Byłem tak bardzo zajęty towarzyszami, że nie miałem czasu na dokonanie czegoś w rodzaju podsumowania naszej ubiegłorocznej działalności. „Polityka” okrzepła, liczy się na prasowym rynku, a z różnych odezwań wnoszę, że towarzysze też ją uważnie czytają. Rozszerzył się także krąg autorów. Magda (Fikusowa) przyniosła w zębach Maćka Kowalskiego, asystenta na Wydziale Biologii. Maciej zajmuje się popularyzacją nauki. Już pierwsze jego teksty wskazują, że ma talent. Zmienił nazwisko na Iłowiecki ponieważ Kowalskich jest jak psów, Zdaje się, że jest to nazwisko jego matki. [...] Maciek jest spokojnym, układnym dobrze wychowanym chłopcem. W minionym roku pozyskaliśmy także wielu nowych autorów. Stanisław Albinowski, Stefan Arski, Jerzy W. Borejsza, syn starego Borejszy, twórcy „Czytelnika”. [...] Skarbem jest Krysia Nastulanka, Michał Hofman pisze „Tekę kronikarza”. Trochę nudnie, ale zna problematykę międzynarodową na wylot. [...] Najaktywniejsi z naszego zespołu to [Zygmunt] Kałużyński, [Ryszard] Kapuściński, Stefan Kozicki, [Kazimierz] Koźniewski, Józef Śmietański, Danek [Passent], [Tadeusz] Pasierbiński, Michał [Radgowski], [Henryk] Zdanowski, który chyba będzie jednak dobrym dziennikarzem. Z upływem czasu opada $\mathrm{z}$ niego MSZetowska patyna ${ }^{67}$.

Tego rodzaju dopisków znajdziemy w opublikowanej wersji dzienników wiele, zwłaszcza w odniesieniu do lat sześćdziesiątych. Można sądzić, że Rakowski czuł się zobowiązany, by po latach uzupełniać swój dziennik o refleksje szerszej natury, a także wspominać o osobach, o których w rzeczywistości na bieżąco nie zapisywał niekiedy ani słowa. Takie zabiegi pozwalały wykreować obraz autora jako człowieka o szerokich horyzontach, a także stanowiły rodzaj ukłonu wobec przyjaciół - niekiedy: byłych przyjaciół - którzy w ten sposób wchodzili na karty historii.

Można odnieść wrażenie, że istniały tematy, co do których Rakowski był zdania, że należy poświęcić im więcej miejsca, aniżeli w rzeczywistości poświęcał im prowadząc swój dziennik. Do takich tematów należy działalność tygodnika „Polityka”. Większa część wzmianek poświęconych podsumowaniom działalności redakcji została przez autora dopisana w czasie prac edytorskich, najpewniej

\footnotetext{
${ }^{66}$ M.in. D. Passent, Czy „Dzienniki” mogą kłamać?, „Polityka” 2003, nr 6, s. 71.

${ }^{67}$ HIA, MFR papers, Box 8, Dziennik 1961, k. 1-2 (5 I 1961).
} 
właśnie po to, by uhonorować dawnych współpracowników ${ }^{68}$. Stanowi to z pewnością świadectwo jego przekonania już z lat dziewięćdziesiątych, że o tym fragmencie własnej aktywności warto, lub należy, pisać więcej. Rakowski, znany z tego, że wobec niektórych członków redakcji bywał oschły ${ }^{69}$, pragnął najpewniej prezentować się jako ten, który żelazną ręką kierował polityką personalną w redakcji własnego tygodnika. Lektura „oryginalnej” wersji dziennika każe postawić pytania o to, jak wiele uwagi poświęcał on działalności „Polityki”. Przykładowo, gdy u progu wiosny 1969 r. w redakcji pojawił się Jan Bijak, Rakowski nie odnotował tego w „oryginalnej” wersji zapisków. Dopiero przygotowując je do druku, na marginesie notatek dopisał:

\begin{abstract}
W stopce redakcyjnej nowe nazwisko. Przyszedł do nas, z prasy wiejskiej, Janek Bijak, świetny reporter, który publikował już na łamach „Polityki” swoje utwory. Janek zastąpił Danka w sekretarzowaniu. Passent jest wspaniałym dziennikarzem, bardzo zdolnym publicystą, reportażystą, felietonistą i Bóg wie jeszcze kim, ale współżycie z kolegami to nie bardzo. Po prostu jest konfliktowy. Wydaje mi się, że przeszkadza mu talent. Skoro ja wiem, skoro ja rozumiem, itd., to dlatego inni nie... ${ }^{70}$
\end{abstract}

Zestawienie tych faktów prowadzi do wniosku, że być może należałoby iść o krok dalej i uznać, że w owym czasie redaktor naczelny już raczej „panował” nad redakcją, aniżeli realnie nią kierował.

Elementów, które wskazują, że bieżące kierowanie tygodnikiem nie było dla Rakowskiego tak istotne, jak po latach próbował to przedstawiać, jest więcej. $\mathrm{W}$ „oryginalnej” wersji dziennika nie znalazła się nawet wzmianka na temat tzw. problemowego planu redakcji „Polityki” na rok $1969^{71}$. Zapewne oznacza to, że w styczniu tego roku redaktora naczelnego absorbowały inne sprawy, niż ów projekt, przygotowywany pod kierownictwem Jerzego Urbana ${ }^{72}$. Tymczasem w tradycji tygodnika - a także i w swoistej mitologii politycznej samego Rakowskiego - z czasem urósł on do miana ważnego dokumentu programowego, symbolu poparcia udzielonego technokratycznej modernizacji à la Edward Gierek ${ }^{73}$. Wśród innych argumentów potwierdzających ten tok rozumowania można wymienić fakt, że na etapie przygotowywania dzienników do druku Rakowski dopisał cały fragment poświęcony głośnemu w owym czasie tekstowi Dobry fachowiec, ale bezpartyjny z lata 1971 r. ${ }^{74}$,

${ }^{68}$ Podobnie: HIA, MFR papers, Box 8, Dziennik 1961, k. 101 (31 XII 1961); HIA, MFR papers, Box 9, Dziennik 1964 (20 XII 1964).

${ }^{69}$ Jako barwny przykład podawany jest casus Barbary W. Olszewskiej (Jajakobyły. Spowiedź życia Jerzego Urbana, Warszawa [1992], s. 125-126).

${ }^{70}$ HIA, MFR papers, Box 11, Dziennik 1969, k. 41 (7 III 1969).

${ }^{71}$ HIA, MFR papers, Box 53, Problemowy plan pracy redakcji „Polityki” na rok 1969.

72 Passa. Z Danielem Passentem rozmawia Jan Ordyński, Warszawa 2012, s. 131.

${ }^{73}$ M. Radgowski, „Polityka” i jej czasy. Kronika lat 1957-1980, Warszawa 1981, s. 169-174.

${ }^{74}$ HIA, MFR papers, Box 12, Dziennik 1971, [niepaginowana dwustronicowa notatka: 2 lipca]; por. M.F. Rakowski, Dzienniki polityczne, t. 4: 1969-1971, s. 446-447 (2 VII 1971). 
oraz fali listów, jaka nastąpiła po jego publikacji ${ }^{75}$. Podobnie, po latach dopisane zostały także m.in. fragmenty poświęcone 15 -leciu tygodnika ${ }^{76}$, ocenie działalności „Polityki” w roku $1973^{77}$, artykułowi Jerzego Urbana z kwietnia $1974 \mathrm{r}{ }^{78}$, tekstowi Rakowskiego Zapomniałem powiedzieć... z maja 1976 r. ${ }^{79}$ lub artykułowi Ważne sa proporcje $\mathrm{z}$ czerwca $1977 \mathrm{r} .{ }^{80}$

Można postawić tezę, że mechanizm usunięć i dopisków w dziennikach miał na celu kreowanie przez Rakowskiego pożądanego obrazu samego siebie. Tymczasem, wolno sądzić, że wpisy w „oryginalnej” wersji dziennika nie zawsze pokrywały się z obrazem, jaki pragnąłby stworzyć autor. Najpewniej za nie dość poważne uznał Rakowski swoje zapiski z podróży do USA w 1962 r. Oto wykreślony fragment notatki z sierpnia, przedstawiający wrażenia z podróży samolotowej:

Na wysokości 9 tysięcy metrów zjadłem następujące smaczne i treściwe potrawy: jakaś ryba częściowo faszerowana, kanapka z krewetką, sałatka z pomidorów, kanapka z szynką, kanapka z czymś, kanapka z kawiorem, poziomki ze śmietaną, kompocik mieszany, ciastko, torcik. Jako napoi używałem koniaku francuskiego oraz wina reńskiego. To ostatnie piłem jako pierwsze, a koniak jako drugi już w czasie konsumpcji drugiej fali ${ }^{81}$.

Opis ten wyszedł spod ręki człowieka, który jak na warunki peerelowskie żył wcale nieźle, lecz mimo to brzmi nieledwie jak opowieść parweniusza, który pierwszy raz w życiu może zjeść tak wystawny obiad w tak nietypowym miejscu. Zresztą fakt, iż Rakowski nie czuł się dobrze w luksusowych restauracjach nie uszedł również uwagi gospodarzy jego amerykańskiej wizyty w $1962 \mathrm{r}^{82}$ Nie jest to jedyny fragment, który autor usunął z tekstu, przygotowując edycję Dzienników politycznych, a który wydaje się frapujący z perspektywy badaczy historii społecznej czy też mentalności elit komunistycznych. Oto jak - w jednym z usuniętych fragmentów zapisków - jawił się Rakowskiemu Nowy Jork, gdy we wrześniu 1962 r. po raz pierwszy zobaczył Amerykę:

Wieczorem po Brodway'u i okolicach. Rzeczywiście jest tak jak to już tysiące razy opisywano. Morze światła, duży ruch w nocy około godziny dwunastej, wszystkie sklepy otwarte, hałas,

${ }^{75}$ HIA, MFR papers, Box 12, Dziennik 1971, k. 66 (24 VII 1971); Zob. Dzienniki polityczne..., t. 4, s. 451 (24 VII 1971).

${ }^{76}$ HIA, MFR papers, Box 12, Dziennik 1972 [niepaginowana, dwustronicowa notatka: 27 lutego]; Dzienniki polityczne..., t. 5, s. 22-24.

77 HIA, MFR papers, Box 12, Dziennik 1973, k. 25-27 (31 XII 1973).

${ }^{78}$ HIA, MFR papers, Box 13, Dziennik 1974 [niepaginowany dopisek 7 kwietnia].

${ }^{79}$ HIA, MFR papers, Box 13, Dziennik 1976 [niepaginowany dopisek, 14 czerwca].

${ }^{80}$ HIA, MFR papers, Box 14, Dziennik 1977 [niepaginowany dopisek, 8 lipca].

${ }^{81}$ HIA, MFR papers, Box 1, Dziennik - t. 6a, k. 2 (24 VIII 1962).

${ }^{82}$ National Archives, General Records of the Department of State, Bureau of European Affairs, Office of Eastern European Affairs Records relating to Polish Affairs, 1952-1963, GR 59 Eur_EE 1952-1963, box 1, Bernard S. Morris to Roger Hilsman, 20 XII 1962, k. 2 (za udostępnienie dokumentu dziękuję dr. Krzysztofowi Persakowi). 
szum, dziesiątki kin huczy muzyką. Prawie na każdym kroku przedsiębiorstwa rozrywkowe. Oczywiście cholernie dużo tandety, mnóstwo strasznie głupawych zabawek. Z Bożeną bawimy się automatami. Kolosalne. Wrzucasz dziesięć centów, naciskasz guzik i szklaneczka papierowa (np. z sokiem pomarańczowym) plus nieodłączny lód wyskakuje przed Twoim nosem. Co najdziwniejsze, automaty pracują bez zarzutu. Reklamy najzwyklejsze i najdziwniejsze. Skayscrepery robią rzeczywiście duże wrażenie. Te starsze, chyba z lat przedwojennych na ogół parszywe i brzydkie, te nowe, budowane po wojnie względnie co dopiero ukończone bardzo ładne i godne podziwu. Rockefeller Centre robi imponujące wrażenie. Sklepy oświetlone, wystawy pomysłowe. Śmieszne ceny. Buciki pewnej klasy zawsze kosztują np. 5 dolarów i 99 centów, a więc nie sześśc ${ }^{83}$.

Być może krępująca dla Rakowskiego byłaby widoczna w tych fragmentach dziennika nieznajomość realiów Zachodu, kłócąca się z kreowanym przez niego obrazem człowieka bywałego, czy wręcz - prawdziwego światowca. Z drugiej strony, być może fakt, że zgniły kapitalistyczny Zachód tak ewidentnie go fascynował powodował, że wstydził się własnej obłudy? Z punktu widzenia historyka efektem takiego zabiegu jest jednak spłaszczenie perspektywy: trudniej dostrzec, kiedy autor rzeczywiście zaczął zyskiwać światowy sznyt, którym przy różnych okazjach lubił błyszczeć. Rakowskiemu zdarzały się też oceny polityczne, które można było - jak sądzę - po latach interpretować jako niezręczne. Jako takie mogły się jawić notatki z końca kwietnia 1969 r., gdy tak pisał o końcu prezydentury Charles'a de Gaulle’a: „Ja osobiście cieszę z jego odejścia ponieważ był to ten człowiek, który zaszczepił na nowo Europie nacjonalizm, to on spowodował obudzenie się tego potworka. Nie ma więc potrzeby żałować go"84. Tymczasem choć pojmowanie polityki zagranicznej w kategoriach marksistowskich nie było w PRL szczególnie popularne, Rakowski był przez długie lata konsekwentnym orędownikiem takiego spojrzenia. Ślady tego nie mniej konsekwentnie pousuwał z kart opublikowanych Dzienników politycznych.

Dość nietypowe usunięcie można odnaleźć w notatkach z jesieni 1959 r., gdy najwyższe władze partyjne nie zgodziły się na wyjazd Rakowskiego do USA. Wyraźnie zły i rozgoryczony zapisywał wówczas: „Jak się czuję? Mam tego wszystkiego dość. Już nie wróci ta resztka wiary, jaką miałem w Gomułkę. Nie rozumie on chyba, że najłatwiej zranić człowieka. Chlapie językiem, a potem się wycofuje"85. Rakowski najpierw zapisał te słowa $\mathrm{w}$ „oryginalnej” wersji dziennika (zapewne wcześniej przepisując je z odręcznych notatek), a następnie przy jakiejś okazji - najpewniej jeszcze na długo przez myślą o publikacji dziennika - starannie przekreślił. Jest

${ }^{83}$ HIA, MFR papers, Box 1, Dziennik - t. 6a, k. 34-35 (5 IX 1962). Tego fragmentu nie znajdziemy ani w Dziennikach politycznych (Dzienniki polityczne..., t. 1, s. 422-423 (5 IX 1962)); ani w stylizowanej na dziennik próbie reportażu Ameryka wielopiętrowa (M.F. Rakowski, Ameryka wielopiętrowa. Dziennik z podróży, Warszawa 1964, s. 20-23 (5 IX 1962)).

${ }^{84}$ HIA, MFR papers, Box 2, Dziennik - t. 26, k. 4 (28 IV 1969); por. Dzienniki polityczne..., t. 4 , s. 72 (28 IV 1969).

${ }^{85}$ HIA, MFR papers, Box 1, Dziennik - t. 2, k. 10 (17 XI 1959). 
to jedno ze świadectw tego, że był on człowiekiem podatnym na emocje i skłonnym do tego, by nieodpowiadające mu decyzje innych traktować niezmiernie osobiście. Nie zmieniło się to także wtedy, gdy znalazł się na szczytach władzy. Tak brzmi notatka z „oryginalnej” wersji dziennika, datowana na 11 lipca 1981 r.:

Zasadnicza rozmowa z Kanią. „Nie widzę cię, powiedział, w Biurze Politycznym”. Wiem o tym, powiedziałem. A ja nie widzę siebie w rządzie w tej sytuacji. Kania powoływał się na interes Polski. Skądinąd wiem, że Gromyko stanowczo domagał się abym nie wszedł do BP. Do gubernatorów należy więc ostatnie słowo w sprawach Polski. Opuściłem gabinet Kani dobrze zdenerwowany ${ }^{86}$.

Z wersji ostatecznie umieszczonej w wersji opublikowanej przez „Iskry”, otwartą groźbę dymisji zastąpiło sformułowanie „niczego nie będę demonstrował, jednak niewejście do BP będzie miało określone, negatywne skutki jeśli nie dla całej partii, to dla tej części, która rzeczywiście pragnie prawdziwej odnowy" ${ }^{\prime 7}$. Innymi słowy, fakt iż Rakowski groził dymisją z fotela wicepremiera został usunięty z publikowanej wersji dziennika. Dobrze pokazuje to problem, jaki stanowi splot emocji i personaliów - problem, na który można natrafić w każdym tomie Dzienników politycznych.

Już w czasie gdy ukazywały się jego dzienniki, Rakowski dawał do zrozumienia, że obok ograniczenia wulgaryzmów, wprowadzane przez niego modyfikacje dotyczyły ochrony dobrego imienia Wojciecha Jaruzelskiego. Najbardziej znamienne jest w tym kontekście usunięcie z zapisku z 15 grudnia 1970 r. „Dalej trwają zamieszki. W gabinecie G. [omułki - MP] odbyła się konferencja z udziałem 8-miu generałów, w tym także Jaruzelskiego. Omówiono plan użycia wojska i sposób zdławienia rewolty. Jaruzelski zaskoczył obecnych cywilów szybkością decyzji i sprawnością. Przedstawił konkretny plan użycia wojska"88. Autor usunął wzmiankę o gotowości Jaruzelskiego do działania z publikowanej wersji Dzienników politycznych ${ }^{89}$, można sądzić, że nie chciał, aby jego świadectwo zostało użyte w procesie o sprawstwo kierownicze Grudnia 1970, który przez wiele lat toczył się w sądach III RP. Inna rzecz, że relacja Rakowskiego była jedynie zapośredniczona. On sam nie mógł brać udziału w tych naradach, toteż w gruncie rzeczy świadectwo to nie miało wartości większej, niż plotka krążąca po gmachu KC.

Trzeba jednocześnie przyznać, że do 1980 r. Jaruzelski nieczęsto pojawiał się w orbicie zainteresowania Rakowskiego. „Szefem GZP Wojska mianowany został gen. brygady Jaruzelski, rocznik 1922. Do chwili objęcia tego stanowiska nie miał nic wspólnego z pracą polityczną. Wynika $\mathrm{z}$ tego, że będzie to facet, który spełniać będzie wszelkie polecenie Spychalskiego"90 - odnotował Rakowski pod datą 4 czerwca 1960 r. w „oryginalnej” wersji dziennika. W opublikowanej wersji

\footnotetext{
${ }^{86}$ HIA, MFR papers, Box 4, Dzienniki 1981, k. 29 (11 VII 1981).

${ }^{87}$ Dzienniki polityczne..., t. 7, s. 458 (11 VII 1981).

${ }^{88}$ HIA, MFR papers, Box 2, Dziennik - t. 30, k. 42 (15 XII 1970).

${ }^{89}$ Dzienniki polityczne..., t. 4, s. 272 (15 XII 1970).

${ }^{90}$ HIA, MFR papers, Box 1, Dziennik - t. 2, k. 50 (4 VI 1960).
} 
odnajdziemy charakterystyczny dopisek: „Tadek Pióro twierdzi, że Jaruzelski jest bardzo ambitnym generałem i że jest to początek wspinania się po szczeblach kariery” ${ }^{91}$. Oprócz tego, w „oryginalnej” wersji dziennika odnajdziemy m.in. dwa zapisy z maja 1971 r., gdzie Rakowski częstuje Jaruzelskiego soczystym określeniem $^{92}$ i, szerzej, wyraża wobec niego antypatię:

Opowiadał mi TP [Tadeusz Pióro - MP] o generale Jaruzelskim. Byli to kiedyś serdeczni przyjaciele. J. nie miał żadnych tajemnic przed Tadkiem. Otóż w jednej z rozmów, J. powiedział, że musi zrobić karierę. No i robi. Kiedy już pewnego dnia był szefem sztabu generalnego, TP zapytał go czy nie jest zdumiony tą karierą. Ten odpowiedział: wiesz, chwilami, rano gdy budzę się, to sam sobie nie wierzę i zadaję sobie pytanie czy nie jest to sen. Jak widać więc, Wojtuś nieźle sobie życie zaplanował ${ }^{93}$.

Z perspektywy końca lat dziewięćdziesiątych, fragment ten została jednak opatrzony zasadniczo inną pointą: „Kariera Jaruzelskiego, oficera bez wątpienia bardzo zdolnego, jest zrozumiała"94. W innym miejscu, w styczniu 1976 r. Rakowski zdecydował się wygumkować fragment, który - jak wolno sądzić - uznał za stawiający Jaruzelskiego w niekorzystnym świetle. Po zreferowaniu plotek poświęconych jego aktywności na polu działalności wychowawczej, pojawia się konkretny przykład: „M.in. [Jaruzelski] polecił aby w domach wypoczynkowych WP, 75 proc. wyświetlanych filmów było radzieckich, a reszta polskich i z innych krajów socjalistycznych, Na kraje zachodnie minister wyznaczył 5\% repertuaru”95. Wreszcie, w styczniu 1981 r., na kilka dni przed tym, zanim Rakowskiemu złożono ofertę wejścia do rządu kierowanego przez Generała, podsumowywał on, że „co się tyczy Jaruzelskiego to jest to bardzo mierny polityk" ${ }^{\prime \prime}$.

Z kolei, gdy Rakowski wszedł już do rządu Jaruzelskiego, pierwszego dnia piastowania funkcji zapisał m.in. taki passus, który później zdecydował się w całości usunąć:

Skład rządu nie uległ wielkim zmianom. Namawiałem WJ, aby przy tej okazji pozbył się Jagielskiego, ponieważ jest to człowiek leniwy, a także niechętny nam bo sam liczył na to stanowisko. Wojciech przyznał mi rację, ale jednak na taką zmianę się nie odważył. Wicepremierem został także Jedynak, postać dość mierna. Kiedy rozmawiałem z Jagielskim to wyrażał zdziwienie, ze Wojciech chce go mianować wicepremierem. Gdy opowiedziałem o tej rozmowie Wojciechowi to zdziwił się bardzo i oświadczył, że to właśnie Jagielski doradzał mu wzięcie Jedynaka ${ }^{97}$.

${ }^{91}$ Dzienniki polityczne..., t. 1, s. 203 (4 VI 1960).

${ }_{92}$ HIA, MFR papers, Box 2, Dziennik - t. 33, k. 13 (20 V 1971).

${ }_{93}$ HIA, MFR papers, Box 2, Dziennik - t. 33, k. 24-25 (30 V 1971)

${ }^{94}$ Dzienniki polityczne..., t. 4, s. 415.

${ }^{95}$ HIA, MFR papers, Box 3, Dziennik - t. 40, k. 46 (27 I 1976); Zob. M.F. Rakowski, Dzienniki polityczne..., t. 6, 1976-1978, Warszawa 2002, s. 28 (27 I 1976).

${ }^{96}$ HIA, MFR papers, Box 4, Dziennik 1981, k. 4 (12 I 1981); M.F. Rakowski, Dzienniki 1981 - kopia, w zbiorach autora. Por. Dzienniki polityczne..., t. 7, s. 312 (12 I 1981)

${ }_{97}$ M.F. Rakowski, Dzienniki 1981 - kopia, w zbiorach autora (12 II 1981); HIA, MFR papers, Box 4 , Dzienniki 1981, k. 17 (12 II 1981). 
Niewykluczone, że Rakowski chciał ochronić pamięć o Mieczysławie Jagielskim lub uniknąć ostrej krytyki pod adresem Andrzeja Jedynaka. Moim zdaniem najbardziej przekonująca jest jednak hipoteza, iż Rakowski usunął ten zapisek dlatego że - trochę przypadkiem - uwiecznił w nim pierwszą z wielu intryg personalnych Jaruzelskiego jakich był świadkiem, i mimowolnym uczestnikiem, w latach osiemdziesiątych.

Badacze, którzy oczekiwali, że w „oryginalnej” wersji dzienników Rakowski nie oszczędzał Jaruzelskiego, mogą poczuć się zawiedzeni. Chyba najostrzejszą opinią sformułowaną pro foro interno była ta z listopada 1991 r., a więc w czasie, którego edycja Dzienników politycznych nie obejmuje:

obwiniam Jaruzelskiego, że faktycznie (w latach 80.) nie miał najmniejszego zamiaru podzielić się choćby kawałeczkiem władzy, podobnie jak wykonywał różne gesty reformatorskie, które niczego nie zmieniały. $\mathrm{W}$ drugiej połowie lat 80 . po przyjściu Gorbaczowa można było iść śmiało na głębokie reformy. Kto wie, czy Polska i Europa Wschodnia nie wyglądałaby inaczej gdybyśmy poszli w kierunku śmiałego reformowania zarówno systemu ekonomicznego jak i politycznego. Dziś musimy łykać upokorzenia i oskarżenia ${ }^{98}$.

Podobna w tonie była ocena $\mathrm{z}$ grudnia tego samego roku:

Mój stosunek do niego od pewnego czasu ulega przewartościowaniu. Nie chcę tego publicznie powiedzieć, ale uważam, że Wojciech ponosi główną odpowiedzialność za to, że w tak głupi sposób utraciliśmy władzę. Rzecz w tym, że był on jedynie politykiem od ustawiania na scenie dekoracji reformatorskich, a w rzeczywistości nie był skłonny podzielić się władzą choćby tyle co brudu za paznokciem ${ }^{99}$.

Wbrew zapowiedziom Rakowskiego, to nie oceny Jaruzelskiego zostały złagodzone w największym stopniu. Najbardziej konsekwentnie usuwane były - nader liczne - krytyczne uwagi pod adresem Andrzeja Werblana. Sądząc z zapisów w „oryginalnej” wersji dziennika, autorowi było z nim nie po drodze zwłaszcza w okresie od Marca 1968 aż do połowy lat siedemdziesiątych. Po latach autor zdecydował się usunąć swoje dawne opinie, chociaż ich charakter nie wskazuje, by były podyktowane przejściowym wzburzeniem czy powierzchowną oceną. W styczniu 1971 r. Rakowski zapisywał w „oryginalnej” wersji dziennika: „Nota bene dowiedziałem się teraz, że to właśnie Werblan chwalił się tym, iż w marcu właśnie on z Kępą aranżowali całą sprawę rozpędzania wiecu studentów"100; tymczasem

\footnotetext{
${ }^{98}$ HIA, MFR papers, Box 7, Dziennik 1991, k. 192 (11 XI 1991).

${ }^{99}$ HIA, MFR papers, Box 7, Dziennik 1991, k. 199 (16 XII 1991).

${ }^{100}$ HIA, MFR papers, Box 12, Dziennik 1971, (11 I 1971), k. 27; Box 2, Dziennik - t. 31, k. 27 (11 I 1971). Ta sama myśl powtórzona kilka dni później: „Werblan w rozmowie z AS szczycił się tym, iż w marcu 1968 roku wspólnie z Kępą podjęli decyzję o rozpędzeniu wiecu studentów - dodajmy w momencie, gdy wiec się już skończył", HIA, MFR papers, Box 2, Dziennik - t. 31, k. 33 (22 I 1971); ona również została wykreślona z opublikowanej wersji dzienników (Dzienniki polityczne..., t. 5, s. 328).
} 
w opublikowanej wersji Dzienników politycznych przeczytamy: „Notabene uzyskałem teraz potwierdzenie, że to właśnie Kępa aranżował rozpędzanie wiecu studentów”101. W wersji „Iskier” postać Werblana nie jest nawet wspomniana w tym kontekście.

Krytycznych ocen Werblana zapisanych przez Rakowskiego w pierwszej połowie lat siedemdziesiątych jest multum. Na przykład przy okazji odsunięcia go na boczny tor w lutym 1971 r.- gdy objął stanowisko wicemarszałka Sejmu PRL - Rakowski zanotował: „co się tyczy Andrzeja, to nie boleję nad nim. Jest to wyjątkowy [...] intrygant. O tyle niebezpieczny, iż bardzo inteligentny. Czego ten człowiek chce? Chyba tylko władzy"102. Z kolei w maju $1974 \mathrm{r}$ pisał o Werblanie, że „należał do tych, którzy w marcu 1968 roku pracowali uczciwie na rzecz przedstawienia Polski w jak najgorszym świetle. Jego artykuł w «Miesięczniku Literackim» został przez wielu komunistów (również poza granicami naszego kraju) uznany za przejaw obskuranckiej myśli politycznej”"103. Po obu opiniach nie został w Dziennikach politycznych żaden ślad. Natomiast w styczniu 1976 r., przypisując Werblanowi czołowe znacznie w kampanii propagandowej wokół zmian w Konstytucji PRL, Rakowski zapisał w „oryginalnej” wersji dziennika, że „na tle zmęczenia i jakiejś obojętności jednych (np. Kraśko, Tejchma), braku odwagi $\mathrm{u}$ innych, koncentrowania się jeszcze innych na wąskich problemach (technokraci w rządzie i w KC) swobodnie hulają tacy ludzie jak Werblan, Łukaszewicz i cała czereda"104. Po poprawkach autora wprowadzonych w szóstym tomie Dzienników politycznych, pozostało zdanie: „Na tle zmęczenia i jakiejś obojętności jednych, braku odwagi innych, koncentrowania się jeszcze innych na wąskich problemach (technokraci w rządzie i w KC), swobodnie hula cała czereda facetów"105. Tego rodzaju przykładów znaleźć można u Rakowskiego znacznie więcej. Rzadkie są miejsca, gdy autor zdaje się mrugać do czytelnika. Tak intepretuję los zapisu z „oryginalnego” dziennika z 9 września 1973 r.:

Nie odnotowałem rozmowy jaką parę tygodni temu odbyłem z Werblanem. Jest to człowiek zdecydowanie zły, zafascynowany władzą, a ściślej możliwościami manipulacyjnymi jakie ona stwarza. Rozwijał przede mną całą teorię socjalistycznego parlamentaryzmu, z której wynikało, że wszelkie próby ożywienia tego tworu, opierające się na doświadczeniu światowego parlamentaryzmu są skazane na przegraną. Kpił z demokracji parlamentarnej, ze wszystkich koncepcji głoszących możliwość ożywienia tego cudaka jakim jest Sejm. Jest to, jak już zdążyłem sprawdzić, instytucja kompletnie martwa, a ściślej wyłącznie narzędzie w rękach Wydziału

\footnotetext{
${ }^{101}$ M.F. Rakowski, Dzienniki polityczne..., t. 4, s. 308 (11 I 1971).

${ }^{102}$ HIA, MFR papers, Box 2, Dziennik - t. 32, k. 13 (23 II 1971); por. Dzienniki polityczne..., t. 4, s. 370 (23 II 1971).

${ }^{103}$ HIA, MFR papers, Box 3, Dziennik - t. 37, k. 36 (10 V 1974); por. Dzienniki polityczne..., t. 5, s. 238 (10 V 1974)

${ }^{104}$ HIA, MFR papers, Box 3, Dziennik - t. 40, k. 48 (28 I 1976).

${ }^{105}$ Dzienniki polityczne..., t. 6, s. 30 (28 I 1976).
} 
Organizacyjnego KC. Posłowie są traktowani jak barany. Nie ma mowy o tym, aby sejm stał się forum dyskusyjnym ${ }^{106}$.

Zamiast tej notatki, w Dziennikach politycznych odnajdziemy zupełnie inną, którą można potraktować jako frapujący - lecz i bardzo wyjątkowy - metakomentarz do wykreślonej treści:

Ja chyba nie jestem całkiem normalny. Żyję polityką tak bardzo, że nawet sny mam polityczne. Czasem budzę się, bo mam w łóżku co najmniej kilku członków Biura Politycznego. W snach dyskutuję z nimi, wykłócam się o jakieś duperele itp. Gdy później pamiętam jeszcze sen, to śmieję się sam z siebie ${ }^{107}$.

Można sądzić, że głównym powodem, dla którego Rakowski zdecydował się wyretuszować swoje niezmiernie krytyczne opinie wobec Werblana był fakt, że na politycznej emeryturze pozostawali w bliskiej zażyłości, m.in. współpracując przy tworzeniu miesięcznika „Dziś. Przegląd Społeczny” 108 . Trudno wyobrazić sobie, żeby obaj nie rozmawiali na temat zawartości Dzienników politycznych. Niewykluczone, że autor poczuł się zobowiązany do tego, by w imię znajomości powstrzymać się od publikacji swoich dawniejszych sądów.

Wolno sądzić, że casus Werblana nie był odosobniony. Jednym z bliskich znajomych w ostatnich latach życia Rakowskiego pozostawał Janusz Roszkowski, choć ich wzajemne relacje nie zawsze były tak dobre. W „oryginalnej” wersji dzienników Rakowski pisał o spotkaniu w Katowicach we wrześniu 1971 r., gdzie był on przedstawicielem Stowarzyszenia Dziennikarzy Polskich: „referat wygłosił Roszkowski, wiceprezes tej śmierdzącej organizacji, typek nieciekawy, ale piekielnie ambitny”109. W Dziennikach politycznych pozostała opinia: „Referat wygłosił Roszkowski, wiceprezes tej organizacji, bardzo ambitny facet" ${ }^{\prime 10}$. Z kolei dwa lata później, tak notował we wrześniu 1973 r.: „W PAP-ie natomiast królują absolutne zera. Szefem jest Roszkowski, mierny dziennikarz, za to bardzo dobry włazidup. Należy do szajki zaufanych Wydziału Propagandy. W tym roku otrzymał Nagrodę im. Prusa. Pusty śmiech człowieka ogarnia"111. W piątym tomie Dzienników politycznych czytelnik pozna opinię, która tylko w najbardziej generalnych zarysach przypomina tę pierwotną: „W PAP-ie natomiast królują przeciętniacy. Szefem jest Roszkowski [Janusz], który cieszy się zaufaniem Wydziału Propagandy.

\footnotetext{
${ }^{106}$ HIA, MFR papers, Box 3, Dziennik - t. 35, k. 98 (9 IX 1973); HIA, MFR papers, Box 12, Dziennik 1973, k. 98 (9 IX 1973).

107 Dzienniki polityczne..., t. 5, s. 156 (9 IX 1973).

108 A. Werblan, Polska Ludowa. Postscriptum, Warszawa 2019, s. 366; K. Wasilewski, Inna wizja transformacji. Polityka wewnętrzna i zagraniczna Polski w świetle publicystyki miesięcznika „Dzis Przegląd Społeczny" (1990-2008), Toruń 2012, s. 54.

${ }^{109}$ HIA, MFR papers, Box 2, Dziennik - t. 33, k. 74 (12 IX 1971).

${ }^{110}$ Dzienniki polityczne..., t. 4, s. 458 (12 IX 1971).

${ }^{111}$ HIA, MFR papers, Box 3, Dziennik - t. 35, k. 99 (12 IX 1973).
} 
W tym roku otrzymał Nagrodę im. Prusa"112. W szerszym planie widać, że Rakowski nie tylko zmiękczył - wypada podkreślić, że bardzo zasadniczo - swoje pierwotne opinie. Opisując swoje wrażenia z XI Plenum KC z czerwca 1981 r., Rakowski dopisał ok. 2004 r. taki passus: „Bardzo dzielnie i odważnie wystąpił Janusz Roszkowski, który polemizował z zajadłą krytyką dziennikarzy"113. W złożonej mi relacji, Roszkowski wskazywał, że dyskutował z Rakowskim o krytycznych opiniach, jakie zawarł on na jego temat $\mathrm{w}$ „oryginalnej” wersji dzienników (niektóre z nich ukazały się w pierwszych tomach Dzienników politycznych) ${ }^{114}$. W poważny sposób uprawdopodabnia to tezę, że Rakowski w edytowaniu swoich dzienników czuł się zobowiązany lojalnością wobec niego, by w korzystniejszym świetle przedstawić go kolejnych tomach publikowanych przez „Iskry”. Co za tym idzie, wolno sądzić, że poważna część opinii Rakowskiego wyrażonych w Dziennikach politycznych to w rzeczywistości opinie aktualne w latach 1997-2005, a nie $\mathrm{w}$ momencie, do jakiego zostały przypisane przez autora. Zmiany prawdopodobnie sięgają dalej i dotyczą znacznie większej liczby osób wspominanych na kartach Dzienników politycznych.

Mechanizm rzutowania opinii w przeszłość działał także w stronę przeciwną niż opisałem powyżej. Tak było np. w przypadku Dominika Jastrzębskiego, ministra współpracy gospodarczej z zagranicą, tak charakteryzowanego w opublikowanej wersji Dzienników politycznych w końcu października 1988 r.: „Bystry facet, ale chyba zbyt pewny siebie. [...] Za miesiąc, dwa będę już wiedział, czy przypadkiem nie pomyliłem się, proponując mu stanowisko"115. Po nieco ponad dwóch miesiącach, pod datą 10 stycznia 1989 r. przeczytamy: „Jastrzębski jest zbyt pewny siebie, by nie powiedzieć - zarozumiały; ma w sobie coś z bufona"116. W rzeczywistości możemy tylko podejrzewać, kiedy Rakowski sformułował podobną ocenę, bowiem w pierwotnej wersji dziennika nie znajdziemy żadnej z nich. Jeżeli odwołać się do „oryginalnej” wersji dziennika, wówczas możemy z pewnością stwierdzić, że o Jastrzębskim pisał na własny użytek jako o swojej „największej pomyłce kadrowej" dopiero w marcu 1990 r. ${ }^{117}$

Rakowski niebezzasadnie cieszył się reputacją polityka krytycznego i konsekwentnie dążącego do zmian racjonalizujących funkcjonowanie systemu komunistycznego w Polsce. Nie zmienia to jednak faktu, że praktyka codziennego

\footnotetext{
${ }^{112}$ Dzienniki polityczne..., t. 5, s. 157 (12 IX 1973).

${ }^{113}$ Dzienniki polityczne..., t. 7, s. 442 (15 VI 1981).

${ }^{114}$ Relacja Janusza Roszkowskiego, 25 IV 2017, w zbiorach autora.

${ }^{115}$ Dzienniki polityczne..., t. 10, s. 283 (29 X 1988).

116 Ibidem, s. 334 (10 I 1989).

${ }^{117}$ HIA, MFR papers, Box 6, Dziennik 1990, k. 46 (31 III 1990). Być może znaczenie miała tu ujawniona później odpowiedzialność Jastrzębskiego za aferę alkoholową, która położyła się cieniem na ocenę działalności rządu Rakowskiego (zob. A. Dudek, Od Mazowieckiego do Suchockiej. Pierwsza rządy wolnej Polski, Kraków 2019, s. 186, 193).
} 
funkcjonowania niektórych instytucji systemu musiała być dla niego rzeczą kłopotliwą. Oto w „oryginalnej” wersji dzienników pod datą 20 marca $1974 \mathrm{r}$. zapisywał: „Dla grupki władców PRL, Sejm, podobnie jak KC, to tylko atrapy, a raczej cyrk w którym popisują się różni panowie-klowni. Decyzje zapadają już wcześniej. Wszystko jest wcześniej omówione, ustalone. My, w Sejmie, udajemy jedynie, że o czymś decydujemy"118; w opublikowanej wersji ten fragment został wykreślony ${ }^{119}$. Podobnie stało się m.in. z fragmentem odnoszącym się do kampanii wyborczej do Sejmu PRL w 1980 r.:

\begin{abstract}
Listę kandydatów na posłów ustala kilku facetów w KC. Przyczynek do tej praktyki: w Sejmie VII kadencji był niejaki Bender z Uniwersytetu Katolickiego w Lublinie. Nieźle sobie poczynał, nieraz zjadliwie krytykował władzę ludową. Rezultat? Nie znalazł się już na liście obecnych kandydatów. Ciekawie przebiegała także tzw. kampania wyborcza do Sejmu. Po prostu jej nie było. Nie odbyło się ani jedno spotkanie otwarte z kandydatem na posła. Spotkania były organizowane przez Komitety Partyjne, obecni na sali byli zapraszani. Faktycznie były to spotkania $\mathrm{z}$ aktywem partyjnym i wybranymi przez Komitety ludźmi ${ }^{120}$
\end{abstract}

Trudno jest jednoznacznie wskazać motyw, jaki mógł skłonić Rakowskiego do tego, by usunąć te fragmenty. Skłaniałbym się ku hipotezie, że uznał tę krytykę rzeczywistości za zbyt daleko posuniętą $\mathrm{i}$ - w efekcie - potencjalnie narażającą na śmieszność jego samego jako osobę współodpowiedzialną za ówczesną rzeczywistość polityczną. Zresztą opinie Rakowskiego na temat rzeczywistości politycznej PRL, jakie wyłaniają się z wykreślonych fragmentów bywają momentami zaskakujące, przecząc wykreowanemu przezeń obrazowi „liberała”. Oto np. fragment usuniętej notatki o rozmowie ze Stefanem Olszowskim z 1 czerwca 1977 r.: „Zgadza się ze mną, że każda następna ekipa musi zacząć od chwycenia wszystkich za mordę (również aktywu). Nie ma mowy o liberalizmie, ale trzeba zmienić styl rządzenia, wprowadzić leninowskie normy. Gierek jest do tego niezdolny. Nie ma w tej ekipie, (tej która rzeczywiście rządzi) ludzi, którzy podjęliby się takich zmian”"121. Do konsekwentnie kreowanego obrazu „wewnętrznego opozycjonisty” nie pasowały ani „leninowskie normy”, ani złowróżbne „chwytanie wszystkich za mordę”. Tymczasem bez usunięcia takich cytatów z publikowanych kart dziennika z mitu „liberała” mogłoby pozostać jedynie wspomnienie.

Z publikowanej wersji Dzienników politycznych Rakowski zdecydował się także usunąć pewne ogólne refleksje nad kondycją systemu politycznego w PRL. W marcu 1976 r. zapisywał: „osobiście uważam, że grupa ta jest po prostu bardzo słaba, że wielką politykę robi się pod wpływem chwili, że nie potrafi

\footnotetext{
118 HIA, MFR papers, Box 3, Dziennik - t. 37, k. 8 (20 III 1974).

${ }_{119}$ Dzienniki polityczne..., t. 5, s. 219 (20 III 1974).

${ }^{120}$ HIA, MFR papers, Box 3, Dziennik - t. 48, k. 58 (24 III 1980).

${ }^{121}$ HIA, MFR papers, Dziennik - t. 43, k. 54 (1 VI 1977); Zob. Dzienniki polityczne..., t. 6, s. 216 (1 VI 1977).
} 
ona ogarnąć wielu spraw i że wreszcie stała się potwornie zarozumiała, pewna siebie i nie chce przyjąć żadnej krytyki"122. Z kolei w listopadzie tego samego roku, odnotował: „jeśli kiedyś, w przyszłości, będą się rozliczać z Gierkiem, to sprawa lojalistycznej postawy wobec Kościoła Katolickiego z całą pewnością zostanie mu wyciągnięta. Tak jawnie demonstrowanego sojuszu jeszcze nie było w historii PRL"123. Wydaje się prawdopodobne, że Rakowski wykreślił te oceny zdając sobie sprawę, że brzmią one jak potencjalne zarzuty wobec ekipy Jaruzelskiego, która przecież współpracowała z Kościołem znacznie bliżej, aniżeli ekipa gierkowska. Co więcej, drugi z usuniętych fragmentów wyraźnie potwierdza opinię o Rakowskim jako polityku bardzo krytycznie nastawionym wobec wpływów Kościoła katolickiego, przynajmniej w połowie lat siedemdziesiątych. I w tym sensie ponownie bardziej przypominał przedstawiciela partyjnego betonu niż nastawionego na dialog reprezentanta skrzydła liberalnego.

Zabiegiem, któremu autor dzienników nie mógł się oprzeć, było ukazywanie samego siebie jako człowieka przewidującego, przede wszystkim zaś - przewidującego polityka. Znamiennym przykładem jest choćby sytuacja sprzed III Zjazdu PZPR w marcu 1959 r., kiedy to na porządku dziennym stanęła sprawa powołania Rakowskiego - jako reprezentanta środowiska dziennikarskiego - do Komitetu Centralnego. W opublikowanej wersji Dzienników politycznych przeczytamy: „Ktoś gdzieś podobno słyszał, że mam być wybrany na zastępcę członka KC. Zbyszek Isaak jest tego tak pewien, że założył się ze mną o sześć tomów pamiętników Churchilla. Mogę już czuć się ich właścicielem, ponieważ uważam, że są to zwyczajne plotki"124. Sądząc jednak po tym, że usunął on fragment, w którym Henryka Korotyńskiego, wybranego ostatecznie na zastępcę członka KC, z pasją odsądzał od czci i wiary, określając mianem „faceta bezpryncypialnego, oportunisty" ${ }^{25}$, można sądzić, że w rzeczywistości Rakowski liczył na wybór, wierząc że nadaje się na to stanowisko znacznie bardziej niż Korotyński. W podobnym duchu wybrzmiewało wiele dopisków przewidujących przyszłe wydarzenia polityczne, a nieobecnych w pierwotnej wersji dziennika, np. konstatacja z 24 września 1988 r.: „obawiam się że będą kłopoty z OPZZ. Miodowicz i jego koledzy twardo obstają przy formule «jeden związek w zakładzie pracy», co oznacza, że są przeciwni relegalizacji « $\mathrm{S}_{»}{ }^{126}$. Jak wiadomo, takie problemy na linii OPZZ-kierownictwo PZPR rzeczywiście się pojawiły.

\footnotetext{
${ }^{122}$ HIA, MFR papers, Box 3, Dziennik - t. 41, k. 5 (26 III 1976); zob. Dzienniki polityczne..., t. 6, s. 54 (26 III 1976).

${ }^{123}$ HIA, MFR papers, Box 3, Dziennik - t. 42, k. 50 (25 XI 1976); Dzienniki polityczne ..., t. 6, s. 142 (25 XI 1976).

${ }^{124}$ Dzienniki polityczne..., t. 1, s. 98-99 (17 III 1959).

${ }^{125}$ HIA, MFR papers, Box 1, Dziennik - t. 1, k. 48 (22 III 1959)

${ }^{126}$ HIA, MFR papers, Box 20, Dzienniki 1988, k. 277 (24 IX 1988); Dzienniki polityczne..., t. 10, s. 236 (24 IX 1988).
} 
W niektórych miejscach te zabiegi idą naprawdę daleko. W notatce z 17 kwietnia 1979 r. - która została w całości dopisana post factum ok. 2004 r. - Rakowski zapisał: „Coraz bardziej umacniam się w przekonaniu, że jeszcze w tym wieku dojdzie do zjednoczenia Niemiec"127. Formułowanie takich „przewidywań”, czynionych $\mathrm{w}$ istocie po ziszczeniu się prognozowanych wydarzeń wydaje się zabiegiem dość groteskowym. W rzeczywistości jednak z umiejętnością przewidywania redaktora naczelnego „Polityki” było różnie. Choć w opublikowanych Dziennikach politycznych pod datą 18 grudnia 1976 r. przeczytamy, że „co by się nie stało, przyszłość KOR-u w PRL jest niejasna”"128, to w wersji „oryginalnej” prognoza Rakowskiego brzmiała zgoła odmiennie: „co by się nie stało, KOR nie ma w PRL przyszłości”129. Nie oznacza to jednocześnie, że autor w swych przewidywania permanentnie trafiał kulą w płot. „Czuję, że już gromadzi się proch do następnego wybuchu"130 - zapisywał w maju 1974 r. odnosząc się do nastrojów społecznych. Problem w tym, że po odkryciu kilku naciąganych - a w istocie rzeczy nieprawdziwych - przewidywań przyszłości, trudno powstrzymać się od sceptycyzmu wobec passusów takich, jak ostatni z wyżej cytowanych.

Umiejętność realistycznego spojrzenia to także jeden z przymiotów, które Rakowski cenił sobie w szczególności. Stąd też zapewne chętnie usuwał z treści dziennika elementy, które mogłyby stanowić dowód jego własnej politycznej naiwności. Tak brzmi fragment „oryginalnej” wersji dziennika z 13 stycznia 1969 r., opisujący spotkanie z Józefem Cyrankiewiczem: „Zgłosiłem także swą ochotę do objęcia kierownictwa TV. Powiedziałem, że krążą takie plotki, ale ja chętnie to wezmę i o jednym mogę zapewnić - że będę lojalny wobec kierownictwa"131. W wersji „Iskier” przeczytamy natomiast: „nawiązując do krążącej plotki, że istnieje zamiar powierzenia mi kierownictwa TV, w co nie wierzę, powiedziałem, że gdyby to była prawda, to nie odmówiłbym i na pewno byłbym lojalny wobec kierownictwa"132. Meritum informacji jest rzecz jasna to samo, natomiast opis nastawienia emocjonalnego autora - wręcz przeciwnie. W opublikowanej wersji dziennika Rakowski prezentuje się jako wyraźnie zdystansowany, choć, jak wolno sądzić - choćby tylko w oparciu o pierwotną wersję tekstu - w rzeczywistości wcale tak zdystansowany nie był.

Skala różnorodnych zmian wprowadzonych do dzienników przez Rakowskiego jest ogromna. Nie sprowadza się jednak tylko do wyraźnie dostrzegalnych

\footnotetext{
${ }^{127}$ HIA, MFR papers, Box 15, Dziennik 1979 [niepaginowany dopisek: 17 kwietnia]; Dzienniki polityczne..., t. 7, s. 53 (17 IV 1979).

${ }^{128}$ Dzienniki polityczne..., t. 6, s. 153 (18 XII 1976).

${ }^{129}$ HIA, MFR papers, Box 3, Dziennik - t. 42, k. 66 (18 XII 1976).

${ }^{130}$ HIA, MFR papers, Box 3, Dziennik - t. 37, k. 38 (19 V 1974); por. Dzienniki polityczne..., t. 5, s. 240 (19 V 1974).

${ }^{131}$ HIA, MFR papers, Box 2, Dziennik - t. 25, k. 9 (13 I 1969).

${ }^{132}$ Dzienniki polityczne..., t. 4, s. 17 (13 I 1969).
} 
cięć - wiele z nich jest trudnych do wskazania, a jednak współtworzą one klimat Dzienników politycznych. I tak oto np. w „oryginalnej” wersji dziennika w czerwcu 1964 r. w przeddzień IV Zjazdu PZPR Rakowski pisząc o awansach różnych towarzyszy wspominał o Stanisławie Trepczyńskim, pisząc iż jest to „młody facet z grupy «sekretarzy sekretarzy»" ${ }^{333}$, tymczasem już w wersji opublikowanej określił go jako „mądrego faceta z grupy «sekretarzy sekretarzy»"134. Różnica jest tylko pozornie niewielka, jeżeli zważyć jak w „oryginalnej” wersji Rakowski nie żałował inwektyw innym osobom wymienionym w tej grupie. Podobnie, przy innej okazji, gen. Ignacy Blum został przez Rakowskiego, w „oryginalnej” wersji dzienników, scharakteryzowany jako „stary kapepowiec, b[ardzo]. dobry komunista i człowiek”135. W wersji opublikowanej przez „Iskry”, Blum zostaje określony tylko jako „kapepowiec, bardzo dobry człowiek” ${ }^{136}$.

Skala tego rodzaju drobnych zmian jest bardzo poważna, lecz niemożliwa do precyzyjnego ujęcia bez wyczerpujących badań. Warto jednocześnie wskazać, że zmiany nie dotyczą jedynie subiektywnych ocen. Oto przykład dwóch wersji notatki z 1 marca 1971 r., poświęconej, pozbawionemu większego politycznego znaczenia, spotkaniu Rakowskiego z ekonomistą Józefem Pajestką - odpowiednio „oryginalna” i opublikowana przez „Iskry”:

1.

Spotkałem się dzi[si]aj z Pajestką. M.in. rozmowa o Kępie. Uważa on, że forsowanie Kociołka, to tylko /dla Kępy/ pomost. Obiektywnie rzecz biorąc szum wokół Kociołka jest działaniem przeciwko kierownictwu partii. Jego ocena Kępy i koleżków jest taka jak moja. Kępa czuje, że jeszcze przyjdzie mu zapłacić za Marzec i wobec tego broni się, a najlepszą metodą obrony jest atak. P[ajestka]. uważa, zgadzam się z nim, że rezultatem Marca było niebywałe umocnienie władzy aparatu partyjnego. Teraz ludzie ci obawiają się, że kurs Gierka zachwieje ich pozycjami. ${ }^{137}$ 2.

Spotkałem się dzisiaj z Pajestką, z którym każda rozmowa wzbogaca moją wiedzę o gospodarce. Józek jest jednym $z$ tych ekonomistów, którzy chodzą po ziemi i mają własne zdanie o sprawach dla kraju ważnych. Jest jednocześnie zaprzeczeniem doktrynerstwa i nigdy nie wygłasza sloganów. Trzeźwo i oczywiście krytycznie ocenia politykę gospodarczą kolejnych ekip. Józek, podobnie jak ja, uważa, że rezultatem Marca jest niebywałe umocnienie się władzy aparatu partyjnego. Teraz ludzie ci obawiają się, że polityka Gierka zachwieje ich pozycją"138

Zestawienie obu zapisów pokazuje, że dyskusja dotyczyła partyjnych personaliów - nie zaś, jak zdaje się sugerować notatka zamieszczona w Dziennikach politycznych - gospodarki. Niewątpliwie bowiem, wnioskując z treści „oryginalnego” zapisu, Józef Pajestka był człowiekiem znakomicie zorientowanym w zakulisowym

\footnotetext{
${ }^{133}$ HIA, MFR papers, Box 1, Dziennik - t. 11, k. 2 (10 VI 1964).

${ }^{134}$ Dzienniki polityczne..., t. 2, s. 162 (10 VI 1964).

${ }^{135}$ HIA, MFR papers, Box 1, Dziennik - t. 2, k. 50 (4 VI 1960).

${ }^{136}$ Dzienniki polityczne..., t. 1, s. 203 (5 VI 1960).

${ }^{137}$ HIA, MFR papers, Box 2, Dziennik - t. 32, k. 15-16 (1 III 1971).

${ }^{138}$ Dzienniki polityczne..., t. 4, s. 373 (1 III 1971).
} 
życiu PZPR oraz administracji państwowej i przede wszystkim dlatego Rakowski cenił go jako wartościowego rozmówcę. Pozostaje również sprawą otwartą, czy istniała pomiędzy nimi taka zażyłość, by Rakowski mógł w 1971 r. o Pajestce mówić per "Józek" (nie sugeruje tego oryginalny zapis). Jest to również zmiana drobna, lecz dla Dzienników politycznych charakterystyczna; w wielu innych miejscach w „oryginalnej” wersji dziennika Pajestka pojawia się jako „prof. Pajestka”, co, być może, oznaczało dystans lub szczególny szacunek jaki żywił do niego Rakowski.

Nie ma wątpliwości, że w przygotowywaniu Dzienników politycznych Rakowski wykorzystywał wiele dokumentów. Znakomita większość $\mathrm{z}$ nich pochodziła z jego niezwykle obszernego prywatnego archiwum. Niektóre z nich - o czym wspomniałem wcześniej - zostały przez niego zapisane już na etapie wstępnego segregowania materiału, przy tworzeniu „oryginalnej” wersji dziennika. Nie jest to jednak czynione konsekwentnie i prowadzi miejscami do wyjątkowo kłopotliwych problemów. Np. w ósmym tomie Dzienników politycznych, pod datą 12 grudnia 1981 r., Rakowski zamieścił obszerny cytat $\mathrm{z}$ listu kierowanego do generała Jaruzelskiego ${ }^{139}$. Problem polega jednak na tym, że zacytowany nie został wcale oryginał listu, jaki Rakowski wysłał do Jaruzelskiego, ale jego wersja zacytowana przez tego ostatniego w książce Stan wojenny. Dlaczego... ${ }^{140}$ Gdyby Rakowski sięgnął po list, którego kopia znajduje się zresztą w jego kolekcji przechowywanej w Hoover Institution Archives, dostrzegłby nie tylko, że treść rzeczywistego listu była bardziej dosadna, ale też, że nie został on wysłany 12, lecz 7 grudnia $1981 \mathrm{r}^{141}$ Jest to jeden z przykładów zapożyczania przez Rakowskiego dokumentów lub wypowiedzi od innych polityków komunistycznych. Tego rodzaju praktyk - zwłaszcza w odniesieniu do lat osiemdziesiątych - było znacznie więcej. Z dużą dozą prawdopodobieństwa można stwierdzić, że Rakowskim przygotowującym tom Dzienników politycznych poświęcony okresowi stanu wojennego kierowała chęć potwierdzenia narracji wytworzonej w początku lat dziewięćdziesiątych przez Jaruzelskiego, a tym samym wzmocnienia jej wiarygodności.

Jednocześnie muszę przestrzec przed ekstrapolowaniem powyższych uwag na całą treść opublikowanych Dzienników politycznych. Owszem, w moim przekonaniu nie ulega wątpliwości, że autor potraktował je jako narzędzie autokreacji. We własnym wyobrażeniu pozostawał on politykiem konsekwentnym, „liberalnym” - przy całej umowności tego określenia - a jednocześnie przewidującym i twardo stąpającym po ziemi. Niemało jest jednak w wersji opublikowanej przez „Iskry” fragmentów, które sprawiają wrażenie, jakby mogły być dopisane w trakcie prac przygotowawczych w latach 1997-2005, a tymczasem zostały zapisane w czasach PRL. Oto np. opinia Rakowskiego na temat postawy jego ówczesnej żony Wandy

139 M.F. Rakowski, Dzienniki polityczne, t. 8: 1981-1983, s. 133 (12 XII 1981).

140 W. Jaruzelski, Stan wojenny. Dlaczego..., Warszawa 1992, s. 395-396.

${ }^{141}$ HIA, MFR papers, Box 60, List Mieczysława F. Rakowskiego do Wojciecha Jaruzelskiego, 7 XII 1981. 
Wiłkomirskiej, która wyraziła kategoryczny sprzeciw wobec kampanii poparcia dla zmian w Konstytucji PRL zimą 1976 r.: „No cóż, ma ona rację i trudno cokolwiek jej rzeczowego przeciwstawić. Dobrze, że Wanda tak właśnie myśli i że stać ją na tego rodzaju krok. Nic to nie pomoże, ale przynajmniej zachowa swą godność i ocali godność innych"142. Tego rodzaju przykładów, na przestrzeni z górą trzech dekad prowadzenia zapisków przez Rakowskiego można znaleźć znacznie więcej.

\section{Pakt diarystyczny}

Poza wszelką wątpliwością jest zatem ogromna skala uzupełnień, usunięć oraz przeredagowań, jakich dokonał Mieczysław Rakowski w opublikowanej wersji Dzienników politycznych. W moim przekonaniu takie ustalenie ma bardzo poważne konsekwencje. Nie jest rolą historyka formułowanie zarzutów pod adresem autora, że zdecydował się on spożytkować sporządzane przez siebie notatki dzienne w sposób, jaki uznał za stosowny. Jeżeli rzecz w ogóle rozpatrywać w tego rodzaju kategoriach, Rakowski z pewnością miał prawo do napisania wspomnień, w których przedstawiałby wydarzenia w przyjętej przez siebie perspektywie. Problem leży w czym innym. Rakowski konsekwentnie przedstawiał czytelnikom swoje wspomnienia jako „dziennik”. Tymczasem dziesięciu tomów Dzienników politycznych nie można traktować jako dziennika sensu stricto.

Philippe Lejeune, francuski literaturoznawca, znany przede wszystkim jako twórca konceptu „paktu autobiograficznego”, definiował autobiografię jako „retrospektywną opowieść prozą, gdzie rzeczywista osoba przedstawia swoje losy w ich jednostkowym aspekcie i ze szczególnym uwzględnieniem historii osobowości”. Znamienne jest $\mathrm{w}$ jego ocenie to, że autobiografia tym różni się od dziennika intymnego, iż wizja opowiadania jest $\mathrm{w}$ niej retrospektywna ${ }^{143}$. Innymi słowy, w swoim założeniu dziennik jest formą powstającą na bieżąco i ex definitione pozbawioną waloru interpretowania opisywanych zdarzeń z perspektywy czasu. W niejednym z opublikowanych dzienników odnaleźć można dopiski czy komentarze autorskie dokonane po latach (np. w czasie porządkowania czy przepisywania notatek). W edycjach występują one w formie wyodrębnionego tekstu, niepozostawiającej wątpliwości co do tego, że stanowią uzupełnienie treści zasadniczej. Przykład mogą stanowić choćby dopiski zawarte w trzecim tomie Dzienników Marii Dąbrowskiej, w którym komentuje ona swoje naiwne nadzieje związane z początkami władzy komunistycznej w Polsce ${ }^{144}$.

\footnotetext{
${ }_{142}$ Box 3, Dziennik - t. 40, k. 51-52 (1 II 1976); Dzienniki polityczne..., t. 6, s. 32 (1 II 1976).

${ }^{143} \mathrm{Ph}$. Lejeune, Pakt autobiograficzny, przeł. A.W. Labuda, „Teksty: teoria literatury, krytyka, interpretacja” 1975, nr 5 (23), s. 31-32.

${ }^{144}$ M. Dąbrowska, Dziennik, t. 3: 1945-1950, oprac. T. Drewnowski, Warszawa 1988, passim.
} 
Idąc tropem wskazanym przez Lejeune’a, można założyć, że tak jak on wskazywał na istnienie kontraktu czytelniczego pomiędzy twórcą autobiografii a jej czytelnikiem, podobny - dorozumiany - kontrakt istnieje pomiędzy twórcą dziennika oraz jego czytelnikiem. W przypadku paktu autobiograficznego, obie strony umawiają się ze sobą na to, że tekst przedstawiany przez autora spełnia kryteria przedstawione $\mathrm{w}$ cytowanej powyżej definicji. W przypadku tego, co moglibyśmy nazwać "paktem diarystycznym” autor umawia się z czytelnikiem na to, że przedstawiony przez niego tekst spełni definicyjne kryteria gatunku. Innymi słowy, publikując tekst zatytułowany Dzienniki polityczne, Rakowski sugeruje, że czytelnik otrzyma do rąk zapiski sporządzane dla potrzeb własnych lub w innym celu, składające się z codziennych wpisów, opatrzone datą powstania, lecz przede wszystkim - zapiski bieżące. Dla jasności dodajmy, że przymiotnik „polityczne” miał w zamierzeniach autora oddawać nie jakąkolwiek swoistość gatunkową jego dzieła, ale koncentrację na polityce jako na największej pasji ${ }^{145}$. W końcu, oczekiwania jakie może formułować pod adresem Rakowskiego są tym bardziej zasadne, że 10 tomów jego zapisków ukazało się nie tylko za jego życia, ale w praktyce zostało osobiście przez niego przygotowanych do druku. Niewątpliwie zatem miał on pełną świadomość istnienia określonych ram, w jakich interpretowano kolejne tomy publikowane nakładem „Iskier”. W swoich publicznych wypowiedziach niejednokrotnie podtrzymywał on w czytelnikach przekonanie, że mają do czynienia $\mathrm{z}$ dziennikiem sensu stricto. W rzeczywistości jednak Mieczysław Rakowski z premedytacją złamał "pakt diarystyczny”, na co powyżej przedstawiłem liczne dowody.

Koncepcje poznawcze nadające kategorii „rzeczywistości” czy „przeszłości” jedynie status konstrukcji tekstowych, popularne we współczesnym literaturoznawstwie, prowadzą do zatarcia granicy między prawdą a zmyśleniem ${ }^{146}$. W ten sposób można również potraktować kategorię wiarygodności, co jednak z punktu widzenia badacza faktów historycznych jest niemożliwe do zaakceptowania. Tymczasem sam Rakowski miał zdumiewająco swobodny stosunek do problemu wiarygodności własnych zapisków. Już w 1991 r., w książce Jak to się stało, pisał: „przekazuję Czytelnikom to, co w 1981 r. zapisałem z zaznaczeniem, że nie dokonuję żadnych retuszy". Po takiej deklaracji, zacytował fragmenty prowadzonych ówcześnie dzienników:

6 stycznia

Spotkałem się z J. Klasą. Opowiadał mi o rozmowie Czyrka z Breżniewem (Czyrek był w Moskwie w Święta Bożego Narodzenia). Breżniew jest nadal bardzo zaniepokojony rozwojem sytuacji w PRL. Sytuację w prasie polskiej uważa za zdecydowanie złą ${ }^{147}$.

${ }^{145}$ Dzienniki polityczne..., t. 1, s. 5 .

${ }^{146}$ A. Chomiuk, Fiction czy non-fiction? Uwagi na marginesie pewnego sporu, „Białostockie Studia Literatuoznawcze" 2013, $\mathrm{nr}$ 4, s. 233.

${ }^{147}$ M.F. Rakowski, Jak to się stało..., s. 23. 
Tymczasem ten sam fragment dzienników w wersji „oryginalnej” brzmi:

\begin{abstract}
6 stycznia
Spotkałem się z J. Klasą. Opowiadał mi o rozmowie Czyrka z Breżniewem (Czyrek był w Moskwie w święta Bożego Narodzenia). Breżniew jest nadal bardzo zaniepokojony rozwojem sytuacji w PRL, tylko wymieniał dwa nazwiska - Kani i Jaruzelskiego. W domyśle: tylko do tych dwóch mają zaufanie. Sytuację w prasie polskiej uważa za zdecydowanie $\mathrm{złą}^{148}$. [podkreślenie moje - MP]
\end{abstract}

Innymi słowy, po solennej deklaracji na temat tego, że niczego nie retuszuje, autor dokonał retuszu. Być może w jego subiektywnym przekonaniu powyższa zmiana była uzasadniona - bo nie sposób uznać, żeby miała kosmetyczne znaczenie. Nie zmienia to jednak faktu, że mamy tu do czynienia $z$ zaproponowaniem przez autora określonej konwencji narracyjnej, która natychmiast jest przez niego samego łamana.

W dokładnie taki sam sposób Rakowski postąpił wobec czytelników Dzienników politycznych. We wstępie do pierwszego tomu pisał:

Nie dość, że niczego nie upiększałem, to oparłem się pokusie retuszowania swego wizerunku. Dlatego Czytelnik znajdzie w tych zapiskach moje ówczesne fascynacje, a także niejedną naiwność. Ale taki wtedy byłem. Dziennikiem rządzą inne prawa aniżeli wspomnieniami pisanymi ex post. Nie odmawiając tym drugim wartości, nieraz bezcennych, dają one jednak możliwość wyjaśnienia i komentowania przeżytych lat i wydarzeń, i uczestnictwa w nich autora. W niejedny wspomnieniu piszący je, być może nie zawsze świadomie, skłonny jest przedstawiać siebie w bardziej korzystnym świetle. Dziennik takich pokus i możliwości nie stwarza. Może właśnie dlatego ta forma utrwalania pamięci nie jest przez polityków szczególnie wyróżniana ${ }^{149}$.

Powyższa deklaracja nie pozostawia wątpliwości, że Rakowski ustanawia istnienie paktu diarystycznego pomiędzy nim a czytelnikami Dzienników politycznych. Tymczasem przedstawiane przeze mnie wcześniej przykłady nie pozostawiają wątpliwości co do tego, że nie został on przez autora dotrzymany. Przeciwnie, z premedytacją złamał jego zasady.

\title{
Podsumowanie
}

„W saunie wiedziałem już, że po powrocie do domu i z sauny pisze notatki, ale to mi nie przeszkadzało, bo sam robiłem to samo, tyle że oszczędniej, bo nie miałem dziennikarskiego nawyku [...]. Po dziennikach Mietka nie mam ochoty pisania czegokolwiek, bo zanotował prawie wszystko"150 - zapisał już po śmierci Rakowskiego Józef Tejchma, towarzysz wielu rozmów prowadzonych w saunie,

\footnotetext{
${ }^{148}$ Idem, Dziennik 1981 - kopia, zbiory autora; HIA, MFR papers, Box 4, Dziennik 1981, k. 1.

${ }^{149}$ Idem, Dzienniki polityczne..., t. 1, s. 6.

${ }^{150}$ J. Tejchma, Dialog z przeszłościq otwartą na przyszłość, Warszawa 2014, s. 293.
} 
na basenie czy na spacerach w parku. Nie tylko dawny członek Biura Politycznego, skądinąd autor trzech tomów dziennikó $w^{151}$, był pod wielkim wrażeniem rozległości i szczegółowości zapisków Rakowskiego. Można podejrzewać, że sukces dzieła Rakowskiego natchnął do opublikowania dziennika Władysława Bakę ${ }^{152}$ (choć jego książka jest w znakomitej większości li tylko kompilacją dokumentów, opatrzoną na ogół zdawkowymi komentarzami autora). Dziesięciotomowe monumentalne dzieło Rakowskiego w 2006 roku uhonorowano Nagrodą Historyczną „Polityki”, tą samą, którą on sam kilkadziesiąt lat wcześniej pomagał ufundować.

Wpływ Dzienników politycznych nie tylko na polską historiografię, ale i na rozumienie historii PRL w ogóle, jest trudny do przecenienia. Tym niemniej, czas na weryfikację miejsca, jakie zajmują one w kanonie źródeł do dziejów PRL. W świetle przedstawionych przeze mnie ustaleń twierdzę, że opublikowanych Dzienników politycznych nie można traktować jako dziennika. Jest faktem, że publikacja ta w poważnej części opiera się na autentycznych zapiskach, które powstały na bieżąco. Jednak summa summarum, w Rakowskim nad pasją historyka i dokumentalisty wzięła górę pasja polityczna. Zamiast przedstawić czytelnikom subtelnie jedynie skorygowany - zrozumiałymi względami obyczajowymi - dziennik, zdecydował się na przedstawienie swoistej metaopowieści o PRL, w której pierwszorzędną rolę gra autokreacja twórcy dzieła. Autokreacja ukazująca go jako polityka przewidującego i realistycznego, dalekiego od doktrynerstwa, a zarazem nie chorego na władzę. Jest to wizja, która momentami ma luźny jedynie związek z rzeczywistością.

Kluczowe znaczenie ma to, że Dzienniki polityczne stanowią publikację o charakterze hybrydowym. Niewystarczające wydaje się wskazanie Andrzeja Paczkowskiego, by zachować „ostrożność w korzystaniu z niego dla celów badawczych”, ponieważ nie sposób zaproponować konkretnej metody pracy z tym tekstem, która niwelowałaby jego niewiarygodność. Innymi słowy, nie można zaoferować żadnego skutecznego narzędzia heurystycznego, które pozwoliłby odróżnić w treści opublikowanych Dzienników politycznych fragmenty niepoddane retuszom i te, które zostały wyretuszowane. Taki klucz nie istnieje, bo Dzienniki polityczne to dzieło, które należy traktować jako pokrewne względem wersji „oryginalnej”, lecz tak dalece przetworzone, że w praktyce - zupełnie osobne. W związku z tym, pozwalam sobie sformułować trzy postulaty na przyszłość.

Pierwszym postulatem, jaki z pełnym przekonaniem formułuję $\mathrm{w}$ oparciu o własne badania, jest konieczność traktowania opus magnum Rakowskiego jako li tylko wspomnień ubranych w formę dziennika. Nie oznacza to, że dziesięć tomów Dzienników politycznych należy w bibliotekach przestawić z półki

${ }^{151}$ Idem, Kulisy dymisji. Z dzienników ministra kultury 1974-1977, Kraków 1991; idem, Odszedł Gomułka przyszedł Gierek. Notatki z lat 1971-1973, Toruń 2006; idem, W kręgu nadziei i rozczarowań. Notatki dzienne z lat 1978-1982, Warszawa, 2002.

${ }^{152}$ W. Baka, Zmagania z reforma. Z dziennika politycznego 1980-1990, Warszawa 2007. 
„historia” na półkę „literatura piękna”. Nie kwestionuję totalnie wartości źródłowej tej publikacji, choć bardzo wyraźnie przecenić należy wartość Dzienników politycznych jako źródła do rekonstrukcji dziejów politycznych. Wartość źródłowa dziesięciu tomów opublikowanych nakładem „Iskier” jest niewątpliwie zasadniczo inna, aniżeli próbował nas do tego przekonać ich autor.

Drugą, nasuwającą się naturalnie sugestią, jest opracowanie krytycznego wydania dziennika, które zaprezentowałoby możliwie najbardziej podstawową jego wersję. Realizacja tego zamierzenia byłaby bardzo poważnym wyzwaniem, ale też dopóki taka edycja nie zostanie przygotowana, oddzielenie uzupełnień dokonanych po latach od treści pierwotnej w sposób niebudzący wątpliwości będzie efektywnie niemożliwe. Nie mam wątpliwości, że nie zamknęłaby ona dyskusji nad potencjalną wartością dzienników Rakowskiego dla najnowszych dziejów Polski, ale znakomicie by ją wzbogaciło.

Trzecim postulatem, jaki pragnę sformułować, jest bowiem właśnie sugestia pogłębienia refleksji nad dziennikami Rakowskiego: tak nad ich wersją drukowaną jak i tą, którą określam umownie mianem „oryginalnej” oraz wszystkimi wersjami pośrednimi. W niniejszym tekście przyjmowałem najczęściej perspektywę biografisty, starającego się dotrzeć do faktów prostych, rekonstruującego stan ducha bohatera $\mathrm{w}$ danym historycznie momencie, a także poszukującego zmienności w czasie. Aspektów wartych poruszenia jest przecież znacznie więcej - by wspomnieć choćby to, że kolejne tomy wyraźnie różnią się od siebie, mechanizmy autokreacji zmieniają się, autor nie jest w pełni konsekwentny. Dzienniki polityczne jako zamknięta dziesięciotomowa całość stają się w perspektywie przedstawionych przeze mnie ustaleń nie mniej interesującym przedmiotem badań np. dla literaturoznawców, patrzących przez pryzmat kategorii „biografizmu performatywnego"153.

\section{The Anatomy of Creation. The Case of Political Diaries by Mieczysław F. Rakowski (Summary)}

Mieczysław Rakowski - a long-time editor-in-chief of the Polityka weekly, member of the Central Committee of the Polish United Workers' Party as well as the Prime Minister of People's Poland and the last first secretary of the CC of the PUWP - for at least forty years kept a diary which is a universal, hard to overestimate source to the recent history of Poland. The journal, published by the author in 1998-2005, has gained the status of a unique text, with its author himself guarantying that he had not corrected his notes except for strictly moral matters. A detailed comparison of the published version with the typescripts kept at the Hoover Institution Archives leads to the conclusion that it was quite otherwise. Not only did Rakowski seriously interfere with the original content of his notes, but he also used them deliberately to create the myth of 'political liberal'. To this end, he

${ }^{153}$ K. Drozdowska, Zmagania z mitem. Dorastanie i śmierć w literackiej relacji Linn Ullmann, „Studia Scandinavica" 2018, nr 2 (22), s. 13-18. 
was using different strategies which were thoroughly analysed, proving irrefutably that Mieczysław F. Rakowski's Dzienniki polityczne (Political Diaries) are not diaries in the strict sense, and must be treated as belonging to the genre of memoirs.

\section{Bibliografia}

\section{Źródła niepublikowane}

Archiwum Akt Nowych, Komitet Centralny PZPR, Biuro Prasy

National Archives, General Records of the Department of State, Bureau of European Affairs

Hoover Institution Archives, Mieczysław F. Rakowski papers

Zbiory własne autora

\section{Źródła publikowane}

Baka W., Zmagania z reforma. Z dziennika politycznego 1980-1990, Warszawa 2007

Dąbrowska M., Dziennik, t. 3: 1945-1950, oprac. T. Drewnowski, Warszawa 1988

Gomułka i inni. Dokumenty z archiwum KC (1948-1982), wstęp, wprowadzenia i przypisy J. Andrzejewski [A. Paczkowski], Londyn 1987

Jajakobyly. Spowiedź życia Jerzego Urbana, Warszawa [1992]

Jaruzelski W., Stan wojenny. Dlaczego..., Warszawa 1992

Lata, listy, ludzie. Adresat M.F. Rakowski, Warszawa 1993

Listy do M.F. Rakowskiego. Listopad-grudzień 1982, Warszawa 1983

Masłoń K., Chybiona prognoza, „Rzeczpospolita”, 6-7 VIII 2005

Od sierpnia do grudnia 1980. Listy do Mieczysława F. Rakowskiego, Warszawa 1981

Passent D., Czy „Dzienniki” moga kłamać?, „Polityka” 2003, nr 6, s. 71

Radgowski M., „Polityka” i jej czasy. Kronika lat 1957-1980, Warszawa 1981

Rakowski M.F., Ameryka wielopiętrowa. Dziennik z podróży, Warszawa 1964

Rakowski M.F., Dzienniki polityczne, t. 1-10, 1958-1990, Warszawa 1998-2005

Rakowski M.F., Gorbaczow. Pierwszy i ostatni, Warszawa 1992

Rakowski M.F., Jak to się stało, Warszawa 1991

Rakowski M.F., Polski przekładaniec, t.1-4, Toruń 2002-2007

Stocznia Gdańska Sierpień '83. Listy do wicepremiera M.F. Rakowskiego, Warszawa 1983

Passa. Z Danielem Passentem rozmawia Jan Ordyński, Warszawa 2012

Tejchma J., Dialog z przeszłością otwarta na przyszłość, Warszawa 2014

Tejchma J., Kulisy dymisji. Z dzienników ministra kultury 1974-1977, Kraków 1991

Tejchma J., Odszedł Gomułka przyszed Gierek. Notatki z lat 1971-1973, Torun 2006

Tejchma J., W kregu nadziei i rozczarowań. Notatki dzienne z lat 1978-1982, Warszawa, 2002

Werblan A., Polska Ludowa. Postscriptum, Warszawa 2019

Zanim stane przed trybunałem. Z Mieczysławem Rakowskim rozmawia Dariusz Szymczycha [Warszawa 1992]

\section{Relacje}

Relacja Macieja Siekierskiego, 20 VII 2015 w zbiorach autora

Relacja Wiesława Uchańskiego, 29 VI 2016, w zbiorach autora

Relacja Włodzimierza Rakowskiego, 18 II 2017, w zbiorach autora

Relacja Bronisława Bednarza, 31 III 2015, w zbiorach autora

\section{Opracowania}

Chomiuk A., Fiction czy non-fiction? Uwagi na marginesie pewnego sporu, „Białostockie Studia Literaturoznawcze" 2013 , $\mathrm{nr}$ 4, s. 233-249 
Czapnik S., Rozważny i romantyczny? Wizje socjalizmu w dziennikach Ernesto Che Guevary i Mieczysława F. Rakowskiego, „Nowa Krytyka” 2017, nr 39, s. 99-122

Drozdowska K., Zmagania z mitem. Dorastanie i śmierć w literackiej relacji Linn Ullmann, „Studia Scandinavica" 2018, nr 2 (22), s. 11-25

Dudek A. , Od Mazowieckiego do Suchockiej. Pierwsza rządy wolnej Polski, Kraków 2019

Dwilewicz Ł., Luszniewicz J., Dzienniki polityczne jako klucz do Rakowskiego, w: Ekonomia, społeczeństwo, polityka. Studia ofiarowane prof. dr hab. Januszowi Kalińskiemu w 70. rocznicę urodzin, Warszawa 2012

Eisler J., Siedmiu wspaniałych. Poczet pierwszych sekretarzy KC PZPR, Warszawa 2014

Friszke A., Diariusz Rakowskiego, „Polityka” 2005, nr 37, s. 15-19

Hofman I., Dylematy moralne Mieczysława F. Rakowskiego w „Dziennikach politycznych”, w: Polityka a moralność, red. M. Szyszkowska, T. Kozłowski, Warszawa 2001, s. 145-152

Kosman M., Dokumentalista cieni władzy. Nad dziennikami politycznymi byłego premiera Polski, w: Z rozważań nad kultura polityczna w Polsce. Część druga, Poznań 2001, s. 37-56

Lejeune P., Pakt autobiograficzny, przeł. A.W. Labuda, „Teksty: teoria literatury, krytyka, interpretacja” 1975 , nr 5 (23), s. 31-49

Łatka R., Obraz Kościoła katolickiego w latach osiemdziesiątych w „Dziennikach politycznych” Mieczysława Rakowskiego, „Zeszyty Historyczne WiN- u” 2013, nr 38, s. 121-158

Machcewicz P., „Stuchać potulnie albo odejść”. O Dziennikach politycznych Mieczysława Rakowskiego, w: idem, Spory o historię 2000-2011, Kraków 2012, s. 78-84

Mielczarek T., Dzienniki polityczne 1958-1962, „Rocznik Historii Prasy Polskiej” 1999, nr 1, s. 170-173

Paczkowski A., Pułapki „Dzienników” Rakowskiego, „Polityka” 2013, nr 15, s. 56-57

Przeperski M., Janczar Gomułki. Pozycja polityczna Mieczysława Rakowskiego w latach 1956-1970, „Polska 1944/45-1989. Studia i materiały” 11, 2013, s. 209-233

Różanek B., Grudzień 1981 r. w „Dziennikach politycznych” Mieczystawa F. Rakowskiego - studium źródłoznawcze, praca magisterska napisana pod kierunkiem dr hab. Ewy Syski w Instytucie Historii UAM, 2018 r., mps w zbiorach autora

Stępień S., Dziennik jako źródło do badania historii PRL (na przykładzie "Dzienników politycznych « Mieczysława F. Rakowskiego), w: „Polska 1944/45-1989, Studia i Materiały” 6, 2003, s. 203-228

Świda-Ziemba H., Człowiek wewnętrznie zniewolony. Problemy psychosocjologiczne minionej formacji, Warszawa 1998

Wasilewski K., Inna wizja transformacji. Polityka wewnętrzna i zagraniczna Polski w świetle publicystyki miesięcznika „Dziś Przegląd Społeczny” (1990-2008), Toruń 2012

Wieczorkiewicz P., Jak Rastignac Polskiej Zjednoczonej Partii Robotniczej został Balzakiem Polskiej Republiki Ludowej, „Arcana” 2009, nr 86-87, s. 209-235

Michał Przeperski (ur. 1986), doktor historii, autor rozprawy doktorskiej o działalności politycznej Mieczysława F. Rakowskiego. Pracownik Instytutu Historii Nauki PAN oraz Instytutu Pamięci Narodowej, specjalizuje się w dziejach Europy Środkowej w XX wieku, historii dziennikarstwa i badaniach nad transformacją ustrojową. Autor m.in. książek „Gorące lata trzydzieste. Wydarzenia, które wstrząsnęły Rzeczpospolitą” (2014) i „Nieznośny ciężar braterstwa. Konflikty polsko-czeskie w XX wieku” (2016). Laureat nagrody „Nowych Książek” dla najlepszej książki roku (2017), drugiej nagrody w VII edycji Konkursu im. Inki Brodzkiej-Wald na najlepsze prace doktorskie z dziedziny humanistyki (2019) oraz wyróżnienia w Konkursie na Najlepszy Debiut Historyczny Roku im. Władysława Pobóg-Malinowskiego (2012). Silas Palmer Research Fellow w Stanford University (2015), laureat Stypendium im. Krystyny Kersten (2015), stypendysta Funduszu Wyszehradzkiego w Open Society Archives w Budapeszcie (2019).

Kontakt: m.przeperski@gmail.com 